\title{
Review: Winged bean (Psophocarpus tetragonolobus) cropping systems
}

\author{
GRAHAM E. EAGLETON" \\ Permanent address: 23 Mulhall Street, Wagstaffe, NSW 2257, Australia, "email: grahameagleton@gmail.com
}

Manuscript received: 15 November 2020. Revision accepted: 29 November 2020

\begin{abstract}
Eagleton GE. 2020. Review: Winged bean (Psophocarpus tetragonolobus) cropping systems. Biodiversitas 21: $5927-5946$. Winged bean (Psophocarpus tetragonolobus (L.) DC.) is a rambling, nitrogen-rich, leguminous crop of the Old-World tropics. This review of winged bean (WB) within cropping systems of Southeast Asia and Melanesia revisited four traditional roles that the crop has played: as a minor courtyard vegetable of villages and suburbs throughout the region; as a popular tuber crop in the irrigated plains of Tada-U township in Central Myanmar; as a companion crop in the mixed garden fields of Wamena in Indonesian New Guinea; and as a niche tuber crop in rotation with sweet potato near Goroka in Papua New Guinea (PNG). Drawing upon such traditions, researchers

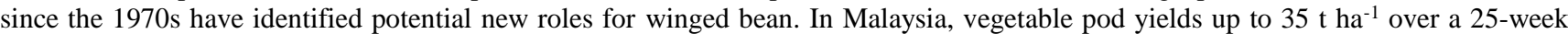
growing period have been obtained from solidly trellised, branching cultivars. Ratooning the crop through a further two cycles covers the cost of the trellising. Tubers from un-trellised field crops in Myanmar, and of staked, pruned garden crops in highland PNG have been estimated to produce crude protein yields of at least $300 \mathrm{~kg} \mathrm{ha}^{-1}$ and $600 \mathrm{~kg} \mathrm{ha}^{-1}$, respectively. Synergies between the gene-pools and cultural traditions would be expected to expand the range, raise the yield and stabilize the quality of tuber crop production. Researchers in Sri Lanka intercropped maize with winged bean. At optimal plant densities, they recorded a corn cob yield of $5 \mathrm{t}$ ha ${ }^{-1}$ together with a cumulative winged bean fresh pod yield of $27 \mathrm{tha}^{-1}$. In Kentucky $\left(38^{0} \mathrm{~N}\right)$, the combination of maize with winged bean to produce silage resulted in 11-18\% greater biomass with $39-67 \%$ greater nitrogen per hectare than maize monocrop control plots. Branching winged bean cultivars have significant potential for benign, high-nitrogen cover and forage crops. Promiscuous nodulation and the development of storage root-systems compensate for slow initial top growth which then accelerates to produce a substantial yield of highly digestible leaf protein and vitamins. Hard-seededness and daylength-sensitive phenology are significant, surmountable, barriers to an expanded role for winged beans.
\end{abstract}

Keywords: Cropping systems, plant protein source, Psophocarpus tetragonolobus, winged bean

\section{INTRODUCTION}

The traditional use of the tropical legume species winged bean (Psophocarpus tetragonolobus (L.) DC.) for its vegetable pods, seeds, leaves and tubers have been investigated by a number of researchers (Burkill 1906; Powell 1974; Claydon 1975; Sastrapradja and AminahLubis 1975; Khan 1976, 1993; Wong 1976; Cerny 1980; Erskine and Kesavan 1982; Chandel et al. 1984; Sri Kantha and Erdman 1984; Harder 1992; Lepcha et al. 2017; Tanzi et al. 2019a) but enthusiastic endeavors in the 1970s and 80s (Cerny and Addy 1973; Masefield 1973; NAS 1975, 1981; Eagleton et al. 1980; Cerny et al. 1981) to expand its development as a high protein crop for the humid tropics met with little success (see PROTA4U 2020 for a current evaluation). In a hard-hitting paper questioning the wisdom and ethical basis of the promotion efforts, Henry et al. 1985 pointed to (i) the high labor requirement in staking the climbing plants for vegetable production; (ii) the high energy cost in rendering the seeds palatable and the modest food value of the end-product relative to other legume species; (iii) and the somewhat inflated useable protein values reported for the edible tubers. They asked (Cerny et al. 1981): "why, if the virtues of the winged bean are indeed as obvious as its advocates claim [had it] not already become a major component of the traditional diets" before the modern phase of research and development activity began.

This paper re-examines the question; especially, the role that winged bean played within the farming systems of Southeast Asia and Melanesia in the era when colonial botanists first became familiar with it. The paper then reviews more recent research on potential winged bean cropping systems and seeks to provide a framework for continuing work into the usefulness of winged bean as a companion species to staple crops, particularly within lowinput farming systems of the tropics and subtropics.

It was Masefield in a series of publications who first drew attention to the vigorous nodulation and nitrogenfixing ability of the species and to its potential role as a cover crop and in rotation with crops like maize and other C-4 grasses. In his 'last word' on the topic, Masefield (1985) pleaded: "Can some institution or some person ... do some experimental work on this aspect to put our knowledge on a scientific footing? If not, I fear that we may be failing in our duty." Sadly, without such efforts, it is likely that winged bean will wither away like so many secondary crops, in the global narrowing of our food production systems (Prescott-Allen and Prescott-Allen 1990; Chappell and La Valle 2011; Khoury et al. 2014, 2016). 


\section{THE DISTRIBUTION OF WINGED BEAN IN THE COLONIAL ERA}

The origins of winged bean (WB) are uncertain; while the other eight confirmed species of Psophocarpus DC. are African, the winged bean is essentially a crop of Asia and the Western Pacific (Verdcourt and Halliday 1978; Harder and Smartt 1992; Fatihah et al. 2012; Yang et al. 2018). At the end of the 19th Century, winged bean had a broadly equatorial distribution (Figure 1), stretching from latitude $21^{0}$ South (Reunion Island) to latitude $25^{\circ}$ North in northeast India (Breon 1820; Chandel et al. 1984). Reunion Island also appeared to represent the most westerly extent of its distribution at longitude 550, while in the east, the distribution reached longitude $155^{\circ}$ in eastern Papua New Guinea (Miklouho-Maclay 1885; Warburg 1899). Its fragmentary appearance in other parts of the tropical world at that time is assumed to have been the result of the activities of botanist and agricultural researchers in the colonial era.

Winged bean occurs in a wide variety of agro-climatic circumstances in tropical Asia and Melanesia. The following section describes farming systems in four typical locations where it has found a niche - Bogor in West Java Province, Indonesia; Tada-U, Mandalay Province, Myanmar; Wamena, Papua Province, Indonesia; and Goroka, Eastern Highlands Province, Papua New Guinea (Table 1). This is followed by a more detailed country-wide analysis of Papua New Guinea farming systems, presented to provide an objective basis for broad generalizations about the role that winged bean might play in future farming systems. A final section reviews more recent research pertaining to these projected winged bean cropping scenarios.

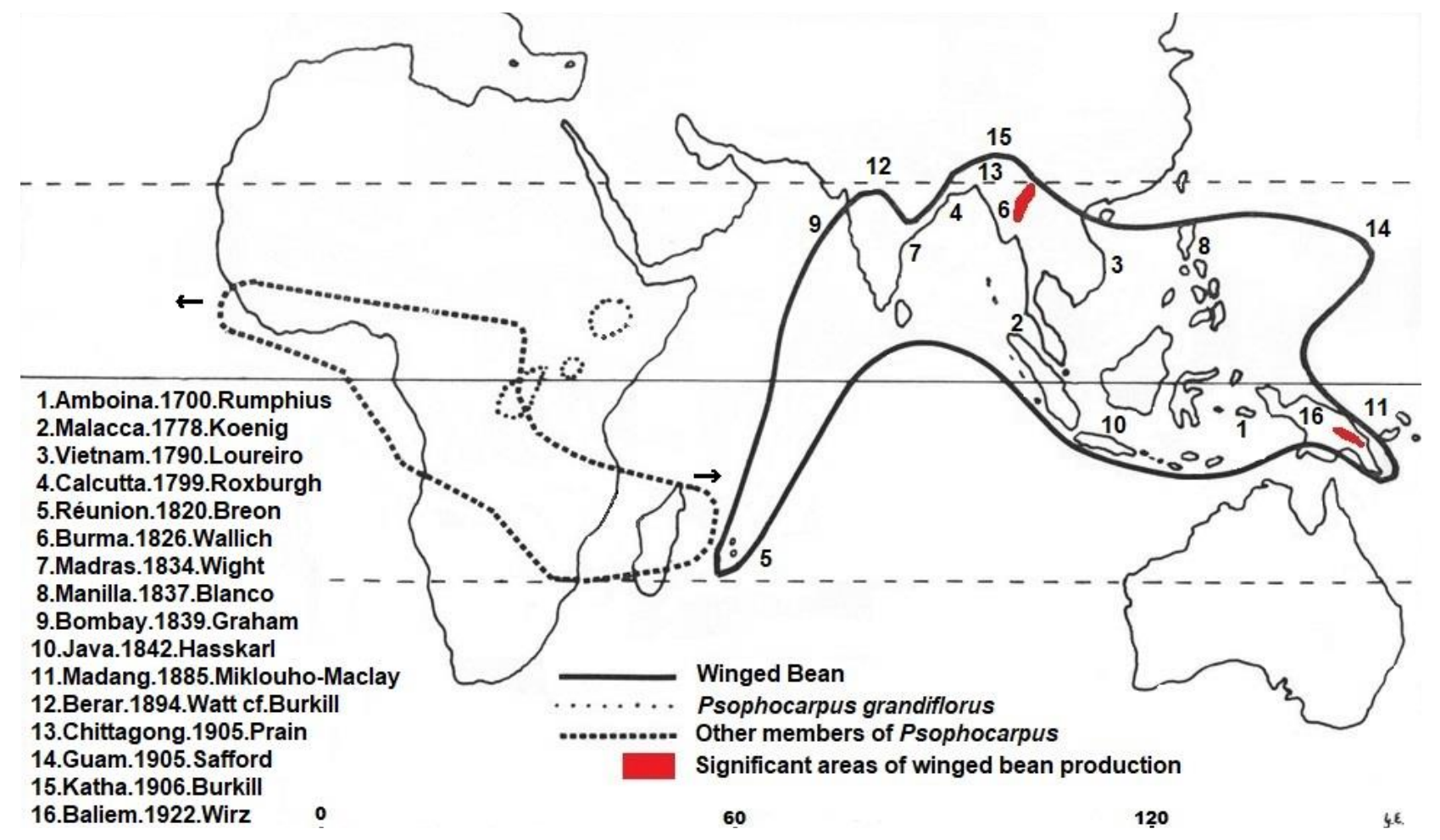

Figure 1. The Indo-Pacific distribution of winged bean (Psophocarpus tetragonolobus (L.) DC.) in relation to the African distribution of other species of the genus Psophocarpus during the era of European colonialism 1700-1920s. One of the African Psophocarpus species, P. scandens (Endl.) Verdc., was distributed widely in the tropics during the colonial era for use as a cover crop (Verdcourt and Halliday 1978)

Table 1. Altitude and climate of four typical locations where winged bean features in traditional farming systems

\begin{tabular}{lcccccc}
\hline \multirow{2}{*}{ Location } & Coordinates & Altitude & \multicolumn{2}{c}{ Temperature $\left({ }^{\mathbf{0}} \mathbf{C}\right)$} & \multicolumn{2}{c}{ Rainfall (mm) } \\
\cline { 3 - 7 } & & $(\mathbf{m}$ asl.) & $\begin{array}{c}\text { Annual mean } \\
\text { maximum }\end{array}$ & $\begin{array}{c}\text { Annual mean } \\
\text { minimum }\end{array}$ & $\begin{array}{c}\text { Mean annual } \\
\text { total }\end{array}$ & $\begin{array}{c}\text { Mean for the driest } \\
\text { 3-month period }\end{array}$ \\
\hline Tada-U & $21.82^{\circ} \mathrm{N} 95.98^{\circ} \mathrm{E}$ & 61 & 33.9 & 22.0 & 817 & 10 (Dec-Jan-Feb) \\
Bogor & $6.60^{\circ} \mathrm{S} 106.80^{\circ} \mathrm{E}$ & 265 & 30.0 & 20.5 & 4,086 & 681 (Jun-Jul-Aug) \\
Wamena & $4.10^{\circ} \mathrm{S} 138.93^{\circ} \mathrm{E}$ & 1,656 & 25.2 & 12.9 & 2,065 & $418(\mathrm{Jun}-\mathrm{Jul}-\mathrm{Aug})$ \\
Goroka & $6.08^{\circ} \mathrm{S} 145.39^{\circ} \mathrm{E}$ & 1,546 & 25.1 & 13.9 & 1,840 & $182(\mathrm{Jun}-\mathrm{Jul}-\mathrm{Aug})$ \\
\hline
\end{tabular}




\section{TRADITIONAL CROPPING SYSTEMS}

\section{Vegetable pod production, South and Southeast Asia}

In Bogor, as in much of Southeast Asia, winged bean is grown as an occasional, 'backyard' crop to supply vegetable pods fresh to the household cooking pot. Small areas are grown on a commercial scale supplying pods to traditional wet markets and in limited amounts to urban supermarkets (Figure 2). In Sri Lanka, Axelson et al. (1982) carried out interviews with villagers in fifteen locations representative of four ecological zones, to determine incidence of production and consumption of winged bean. They found that $57 \%$ of the respondents grew small numbers of plants, primarily in their home gardens. Only the immature, tender pods and leaves were eaten; none of the respondents reported using the mature seed as a food item. A similar situation is found throughout much of southern Asia, from India (including the northeastern states of Manipur and Mizoram) through to Malaysia, Vietnam and south-eastern China, and on to the islands of Indonesia and the Philippines (Merrill 1910; Chomchalow et al.1980; Claydon 1980b; Herath et al. 1980; Jalani and Wong 1980; Mamicpic and Movillon 1980; Pospisil et al. 1981; Haq 1982; Chandel et al. 1984; Wu and Mats Thulin 2010).

The first written report of the cultivation of winged bean for its vegetable pods was that of Rumphius (1747) in the eastern Indonesian island of Amboina at the end of the sixteenth century. Rumphius considered that the plant was not indigenous to the island but had come from further west. Heyne (1927) compiled the limited information available at that time for winged bean cultivation in the archipelago, but it wasn't until the mid-1970s with the work of Sastrapradja and colleagues $(1975,1978)$ in Bogor and of Thompson and Haryono (1980) in Jogjakarta that a comprehensive picture emerged of its cultivation in Java. More recently, Handayani et al. (2015), Kuswanto et al. (2016) and Yulianah et al. (2020) have expanded this picture with a genetic analysis of a wider range of cultivars from Indonesia, particularly East Java.

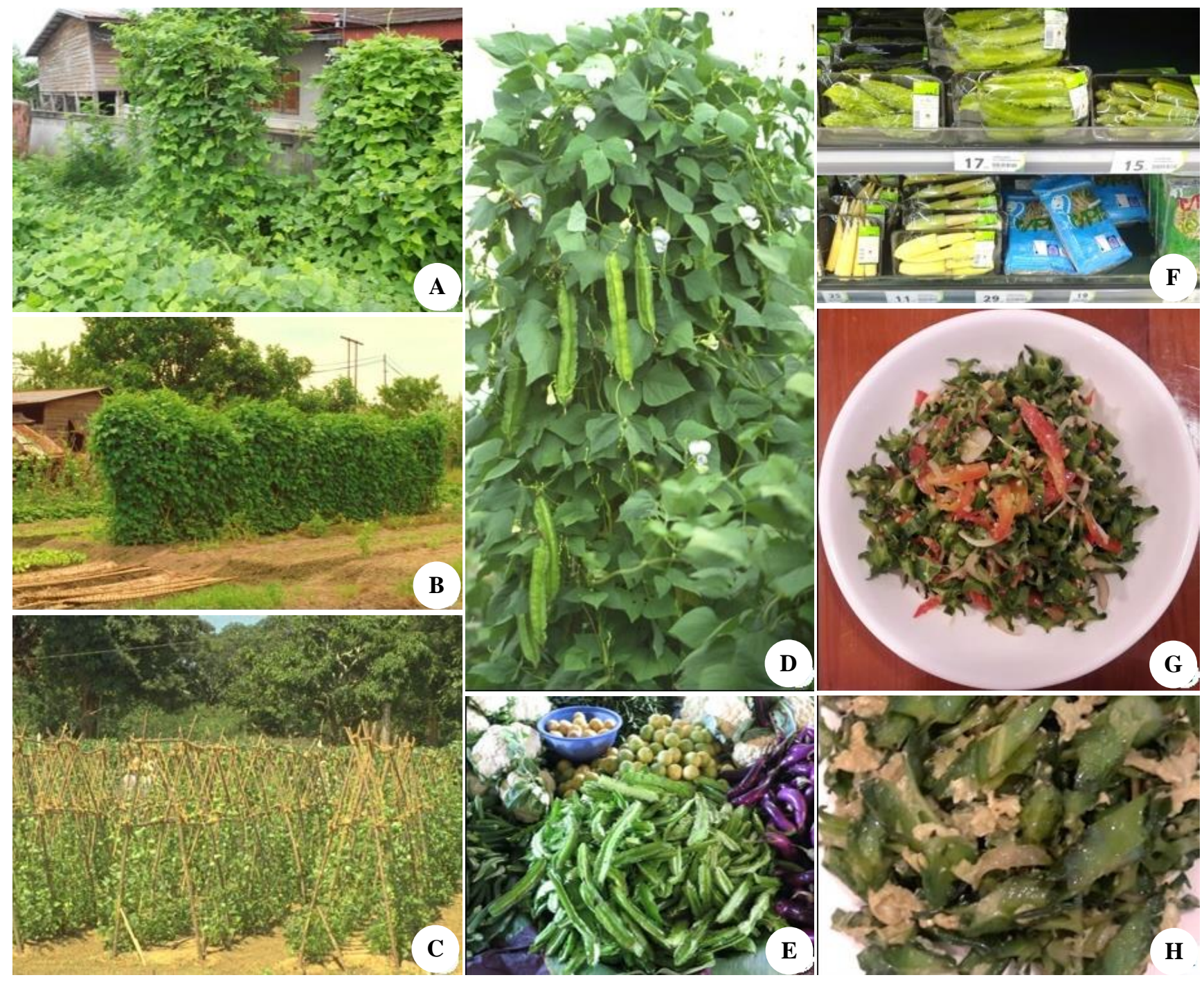

Figure 2. Winged bean is grown as an occasional fresh vegetable crop in most of Southern Asia. A. In rural household compounds (e.g., Khon Kaen, Thailand). B. In urban fringes settings as a local market crop (e.g. Selangor, Malaysia). C. In small, commercial-scale plantings (e.g., Sri Lanka). D. In urban backyards (e.g., Java, Indonesia); E. from which fresh pods may be sold in wet markets; F. or in modern supermarkets; G. to be eaten uncooked in salad dishes; H. or cooked in stir-fries and curries 
Sastrapradja and Aminah-Lubis (1975) classified winged bean as a "minor garden vegetable" used from time to time for its pods, which when picked tender are sauteed or curried in a variety of local dishes for which yard-long beans (Vigna unguiculata subsp. sesquipedalis (L.) Verdc.) or common beans (Phaseolus vulgaris L.) are more usual ingredients. Winged bean seeds at full size but still green and soft are rendered palatable by steam frying, or by boiling along with other vegetables in the popular sour soup known as 'sayur asem'. The authors reported that fully mature dry seeds were sometimes roasted and the kernels are eaten after the hulls sluffed off. However, they noted that in the 1970s mature seed was rarely used as a food item in West Java, but was a more common commodity in markets of eastern Java and Bali. It is possible, though rare, to use the seed as an alternative to soybean seed in the fermented bean cake known as 'tempeh', an important protein ingredient in Javanese cuisine (Gandjar 1980).

In the warm, permanently moist environment of Bogor, local cultivars do not readily form edible tubers. The cultivars are vegetatively vigorous, facultative perennials with strong, stringy root systems. It is common for them to produce edible pods for two to three years in house gardens where daily use can be made of their palatable leaves and flowers at times when pods are scarce on the vine. Even if the plants become infected by the fungal disease Synchytrium psophocarpi, common in the humid growing conditions of Bogor, consumption is acceptable (Heyne1927). Sastrapradja and Aminah Lubis (1975) reported significant phenotypic variation for both qualitative and quantitative characters amongst Javanese cultivars; for example, a remarkable range in length of pods from $12 \mathrm{~cm}$ to $70 \mathrm{~cm}$. In recent studies, Yulianah et al. (2020) have observed more modest differences between cultivar means from 13.7 to $38.4 \mathrm{~cm}$, but noted that for vegetable production, pod length is a pivotal character and highly heritable (Erskine and Kesavan (1982). Also important for efficient vegetable production are the maturity characteristics of cultivars. In Bogor, Sastrapradja et al. (1978) recorded a range of 71 to 149 days for the mean number of days to first open flower among twelve Javanese accessions. More recently, Eagleton (2019) demonstrated that this late maturing behavior of a local Bogor cultivar could be modified by outcrossing to an early maturing introduction followed by selection in the segregating generations. Winged bean cultivars are invariably indeterminate in growth habit across the natural range from South Asia through to the Philippines and New Guinea. One or two exceptions to this (Okubo et al. 1990, Shivashankar and Reddy 1984) have arisen in experimental programs and have yet to impact broadly on plant breeding programs. The indeterminate growth habit and the late maturity of cultivars necessitate expensive trellising to support their growth. This has constrained efforts to expand the commercial production of winged bean pods for fresh vegetable markets.

\section{Tuber production, Mandalay Region, Myanmar}

In southern Myanmar, winged bean is grown for its pods in much the same way as in the rest of Southeast Asia, but in Mandalay Region, it has evolved as a minor field crop grown specifically for its tubers (Figure 3). The cooked tubers are eaten as a snack usually with a sesame and salt sauce. The seed required for planting the tuber crop is produced in the Shan State (Burkill 1906; Eagleton 1999).

In the township of Tada- $\mathrm{U}$, winged bean for tubers is generally planted in the wet season or on residual moisture in the early dry season as a monocrop in fields up to one hectare in size. Supplementary irrigation is required to carry the crop through to mature tuber formation. Often a field is planted to winged bean for a succession of years before being turned over for other crops, such as sunflower, maize, or even wheat. Very occasionally, maize or other free-standing crops are grown at low density along with the tuber crop. Burkill (1906 p 61) noted: "The margin-left to the bone fide cultivators after trouble and expenses would by itself not be encouraging, but the cultivators in Singaing township generally grow a bumper crop of sugar cane in the year after [winged bean]." Other than this report, there appears not to have been an empirical evaluation of the effects of these tuber crops on subsequent crops or of intercrops grown along with the winged bean.

Early estimates for crude protein content (N\% x 6.25) of whole winged bean tubers on a dry weight basis varied from 18\% in Malaysia (Wong 1976) and Nigeria (Evans et al. 1977) to $25 \%$ in Myanmar (Burkill 1906) i.e., equivalent to two to three times the crude protein content of other tropical root crops such as cassava, sweet potato, and yams. However, estimates for crude protein content based on total Kjeldahl N\% of dry matter have been found to over-estimate the potential edible protein content of winged bean tubers for a number of reasons. Firstly, when winged bean tubers are eaten (after cooking) the skin is peeled off and the actual flesh (containing a lower total N\% than the skin) represents only about $75 \%$ of the whole tuber (Poulter 1982). Secondly, non-protein N comprises a significant portion of the total nitrogen content of the edible portion of the tuber.

Evans et al. (1977) estimated the non-amino-acid-N to be around $50 \%$ of the $\mathrm{N}$ measured in the whole tuber. On the other hand, Poulter (1982) determined non-protein $\mathrm{N}$ to be about 13\%, and de Lumen and Reyes (1982) 16\%; while Kortt and Caldwell (1984) found for six winged bean accessions (including one from Myanmar) that non-aminoacid-N accounted for between 7.7 and 16.9\% (mean $12.6 \%$ ) of the total tuber N. Although these laboratory reports differ somewhat in the methods they used, all authors would likely agree with the conclusion of Kortt and Caldwell (1984) that "the non-dialysable protein content of winged bean [tubers] is ... less than previously assumed but is still relatively high for a tuber crop." Unfortunately, it would seem that with the exception of Kortt and Caldwell's study there have been no published analyses of tuber quality specifically on genotypes from Myanmar. Consumption of cooked tubers as a tasty snack has long been popular in Myanmar. Needless to say, it is very likely that witting and unwitting selection down the ages have produced genotypes and preparation methods that reduce the significance of the nutritional limitations perceived in laboratories. 


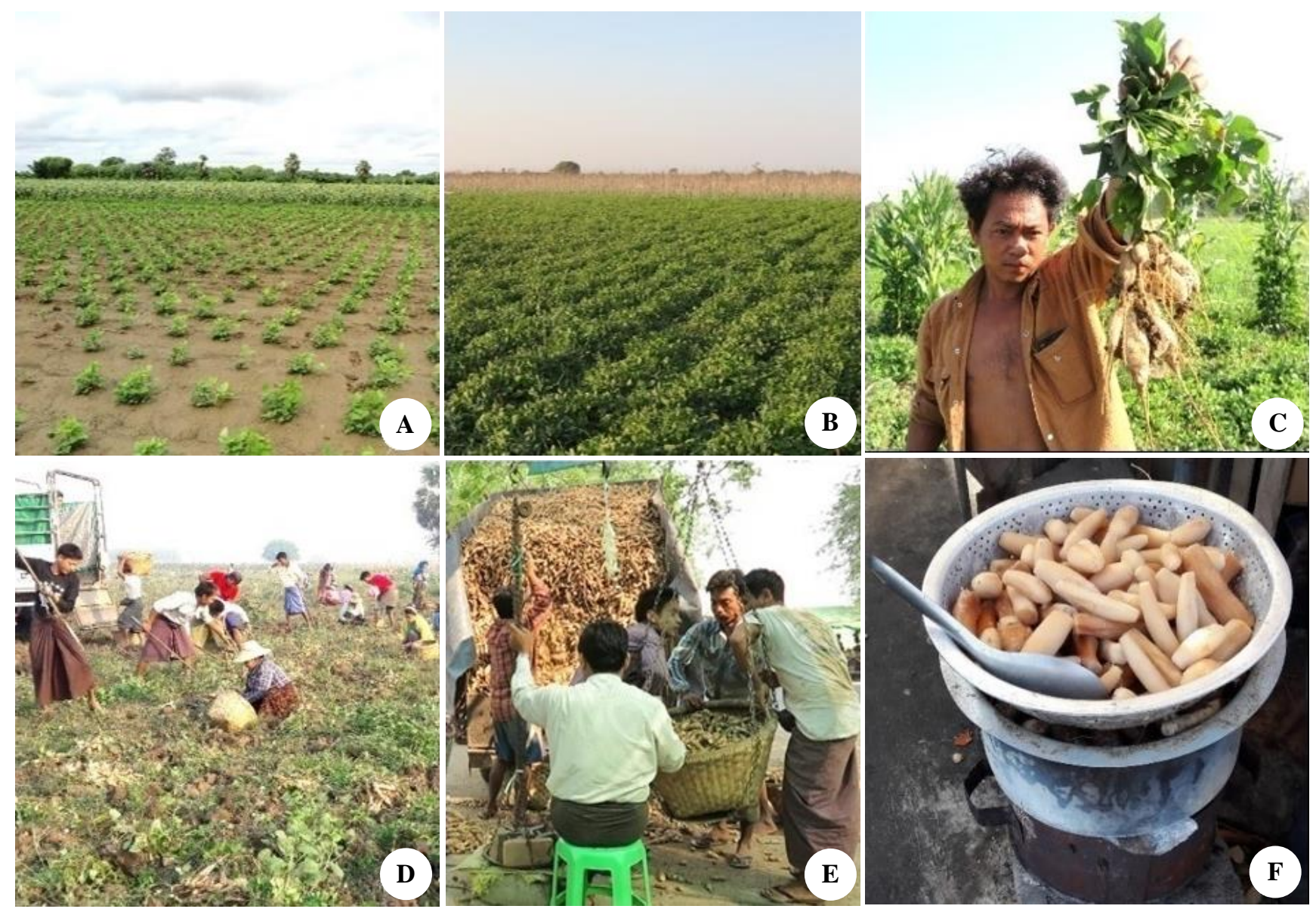

Figure 3. Winged bean is grown for its edible tubers in Tada-U Township, Mandalay Region, Myanmar in 2019. A. One month after planting, with low input sunflowers in the background. B. Nearing tuber maturity five months after planting, with high-input, trellised oriental melons in the background. C. Mature tubers uprooted from a winged bean field in which maize was planted at low plant density. D. Harvesting tubers at optimum stage five months after planting. E. Weighing baskets of freshly harvested tubers. F. Cooking tubers on a three-tiered oven, with hot coals below, steam-cooked intact tubers in the center, and hot, skinned, tuber snacks above.

Edible leaf, pod and seed production, Baliem Valley, Papua Province, Indonesia

Winged bean is grown throughout the island of New Guinea (Verdcourt 1979), although it is less important in coastal cropping systems than in the developed agricultural centers of the highlands. It was first encountered in the 1870 s, on the northeast coast in the vicinity east of Madang (Miklouho-Maclay 1885; Schumann 1899), but it appears that the first certain record of winged bean in the highlands was in the Kremer expedition of 1921-22 (Wirz 1924) to the head-waters of the Baliem Valley of Indonesian Papua. Brass (1941a) and Heider (1970) recorded it among the crops growing in the Grand Valley of the Baliem River, where modern-day Wamena is located today. Lam (1922, 1945) believed that winged bean had been introduced into the highlands, in the same way as sweet potato, maize, and tobacco. These crops of South American origins are thought to have arrived in the highlands less than four centuries ago (Brass 1941b; Yen 1974; Allen 2005; Bourke 2009). On the other hand, Watson (1965) suggested that winged bean might belong with crops like yam, taro, and the legume species kudzu Pueraria montana var. Lobata (Willd.) Sanjappa \& Pradeep to an earlier agricultural era preceding the introduction of sweet potato.

In many parts of highland Papua New Guinea, tuber production is an important objective in growing winged bean, but this seems not to be the case in Indonesian New Guinea (Eng 1985). In January 1995, in a survey by the author of five villages growing winged bean in the Baliem Valley of Papua Province, the consumption or sale of its tubers was never observed; in this part of the highlands, no farmer interviewed in 1995 and again in 2016 indicated that winged bean tubers were a normal part of the food repertoire. On the other hand, fresh pods with full-size green seeds were a daily item in local markets, and in the central market of Wamena city. Traditionally, winged bean pods are steam-cooked along with sweet potato and other vegetables in a communal ground stone oven (Figure 4). It is the cooked seeds and surrounding mucilage that are preferred. 


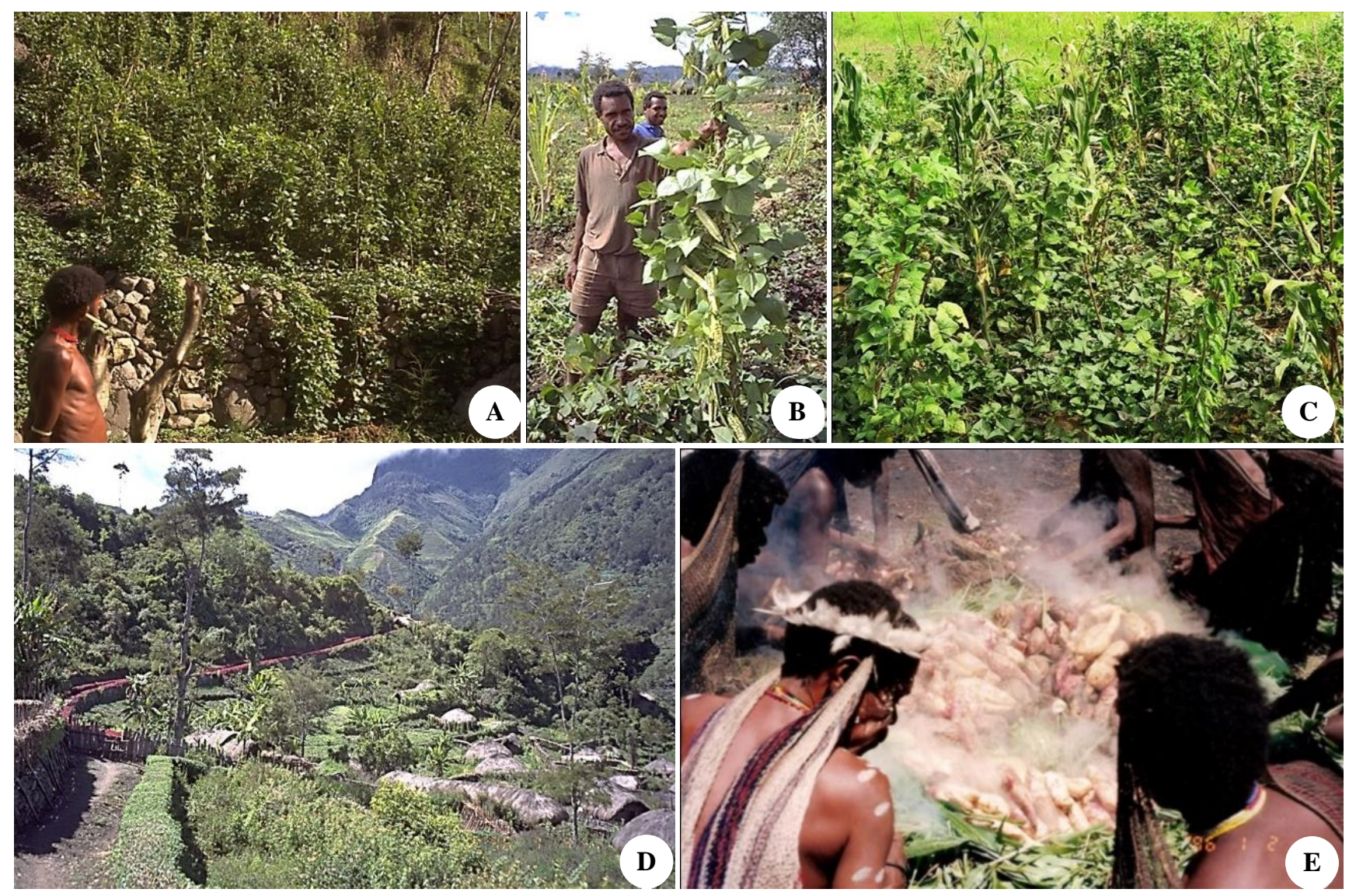

Figure 4. Winged bean along the Baliem valley in the vicinity of Wamena, capital town of Jayawijaya Regency, Papua Province, Indonesia. A. Near the valley bottom, a monocrop of winged bean grown with support of thin, woody, upright stakes on a rock-wall terrace, January 1996. B. Single supported winged bean clumps interspersed within a sweet potato crop. C. A spaced mixed garden crop of sweet potato, maize and winged bean December 2016. D. In villages on slopes up to about $1800 \mathrm{~m}$, patches of winged bean occur in household compounds. E. Leafy shoots and full-length fresh pods are usually steam-cooked in a ground stone oven along with starchy root crops; the cooked winged bean seeds are usually plucked from the pod case and eaten whole.

Winged bean is rarely planted as a monocrop in the Baliem Valley, and then usually in fenced or terraced patches of less than $50 \mathrm{~m}^{2}$ (Figure 4, image A). It is also rare to encounter it in sweet potato swamp fields. More commonly, it is grown in dryer fields ('tegalan' in the Indonesian language) in mixed plantings along with sweet potato, maize and taro; and in fenced slash-and-burn gardens of modest slope up to an altitude of about $1800 \mathrm{~m}$ asl.

In 1941 when Brass described the agriculture of the Baliem valley, he observed only two food legume crops apart from winged bean (i.e., hyacinth bean Lablab purpureus (L.) Sweet, and another unidentified species), which raises an interesting question: if, as Lam (1945 p 149) maintained, the winged bean reached New Guinea shortly after it was "introduced into Amboina during Rumphius' time", why did not the repertoire of other legume crops recorded by Rumphius (Arachis hypogaea L.; Cajanus cajan (L.) Millsp.; Canavalia gladiata (Jacq.) DC.; Clitoria ternatea L.; Glycine max (L.) Merr.; Lablab purpureus L. Sweet; Mucuna pruriens (L.) DC.; Pachyrizus erosus (L.) Urb.; Phaseolus vulgaris L. (?); Vigna radiata (L.) R.Wiczek; Vigna umbellata (Thunb.) Ohwi \& H.Ohashi; Vigna unguiculata (L.) Walp.;
Vigna unguiculata (L.) subsp. sesquipedalis (L.) Verdc.) also reach highland New Guinea (?) If, in fact, some of them did, why was it that winged bean became the principal legume vegetable in the highland larder?

\section{Tuber and pod production, Asaro Valley, Goroka, Eastern Highlands Province, Papua New Guinea}

Prior to the 1870s when colonial incursions initiated a period of rapid new species introductions, winged bean was the most important of four main legume species (winged bean, hyacinth bean, kudzu, and lima bean Phaseolus lunatus L.) incorporated into Papua New Guinea (PNG) food-production systems (Powell 1976; Bourke 2009).

The systems for cultivating winged bean were well established in the vicinity of Mount Hagen township (1,700 $\mathrm{m}$ asl) in Western Highlands Province. They have been described in detail by Powell (1974), Powell et al. (1975), Strathern (1976) and Khan et al. (1977). Winged bean is suited to the rich dark Wahgi Valley soils derived from drained swamplands and to volcanic soils rising to west of the valley (cf. Agricultural Systems 0902 and 0905 in Hide et al. 2002), but small patches are grown further field including on upland ridges approaching $2000 \mathrm{~m}$. 
Around Mount Hagen, winged bean is not usually planted in the main sweet potato areas on the peaty soils of the valley grasslands. Rather, it is planted in mixed garden allotments which in addition to sweet potato include other food crops such as taro, bananas, corn, Amaranthus spinach, leafy vegetables and common beans. The mixed gardens are arranged in a checkerboard pattern of blocks, each about 3-4 $\mathrm{m}^{2}$, separated by ditches dug by men to a depth of 20-30 cm which together drain into larger ditches about $0.7 \mathrm{~m}$ wide and $0.5-1.0 \mathrm{~m}$ deep. The mud from the ditches is piled on top of the individual plots and developed into planting beds by the women. Although strips of plots are managed by individual women, much of the work is undertaken communally with men playing only a minor part in the sowing of the crops and their day-to-day care

Within the mixed garden areas, legume species include lablab; lima bean; and in recent decades, common bean, groundnut, pea (Pisum sativum L.), and sometimes soybean (Glycine max L. (Merr.)) (Powell et al. 1975). But, traditionally, winged bean was the most important of the bean species. Sections of the mixed garden areas up to 0.30.4 ha were dedicated to its cultivation (Khan et al. 1977) with staking support provided by thick stems of pitpit grass (Saccharum spp.) to a height of 2-3 m for vegetable pod production or to a height of $1-1.5 \mathrm{~m}$ for tuber producing varieties. The proportion of winged bean to other crops in the mixed garden areas could sometimes approach 1:5. At higher altitudes, the proportion was likely to be $1: 10$ or less.

In Mount Hagen where the total annual rainfall is around $2500 \mathrm{~mm}$, winged bean is planted in the driest, coolest period from June-August. For pod-producing varieties, the harvest begins 4-5 months after planting and continues for a month or two. The optimal time for harvesting a pod for consumption as a vegetable is around 21 days after flowering while it is still succulent and pliable, but for green pea production, the optimal time is up to 28 days, after which the pod begins to dry down and its seeds harden (Claydon 1983).

For tuber varieties, the digging up of the roots takes place on a single occasion, 6-8 months after planting, at a time when the potential yield of edible roots is judged to be optimal. A crucial practice in the management of winged bean for tubers is that the edible flowers, apical shoots, and young pods are repeatedly removed from the plants to ensure photosynthate is shunted into the root system rather than into the development of pods and seeds. Along with weeding, this is the most-labor intensive activity during the growing phase of winged bean for tubers.

According to Strathern (1976), winged bean was traditionally regarded by the highlanders as a luxury food item. Leafy shoots; flowers; pods with their pre-ripe edible seeds; and root tubers are all consumed after steam-roasting in earthen ovens along with sweet potatoes, other starchy food items, and vegetables. Winged bean tubers impart a nutty fragrance that is much appreciated, so cooking events that include winged bean tend to be communal, even ceremonious, with much emphasis on distribution and gifting. In the pre-colonial era, winged bean was perhaps only second to pigs as a compact source of protein in the predominantly starchy diet (Claydon 1979).

Experimental seed yields of $800-1000 \mathrm{~kg} \mathrm{ha}^{-1}$ from trellised winged bean have been obtained at lowland sites in PNG. In the Western Highlands, in situ field estimates of tuber yields of 5,500 to $11,500 \mathrm{~kg} \mathrm{ha}^{-1}$ have been recorded (Kahn et al (1977). There is considerable diversity among PNG genotypes (Khan 1976; Khan and Erskine 1978). Around Mount Hagen, farmers recognize at least 48 varieties with distinct characteristics, many of real economic significance (Powell 1974). There are varieties known to be best for tuber production, others for pod production, while a few are regarded as dual purpose. Some are known to be hard-seeded, but others have softer seed coats and a pleasant taste. Aspects of this diversity have been explored from a plant breeding point of view (Erskine 1981; Erskine and Khan 1980; Erskine and Kesavan 1982) but much work remains to be done to realize the full potential of the PNG germplasm.

Winged bean is a component of food production systems throughout much of the PNG highlands. In the Asaro Valley, near Goroka, Eastern Highlands Province, winged bean is part of a distinct legume rotation system in which sweet potato, peanut crops and winged bean has grown for tubers are planted on long drained beds about 1.5 $\mathrm{m}$ wide (Figure 5). Men are largely responsible for the land-clearing and bed construction for these crops, but it is usually the women that take care of their cultivation.

The sweet potato is planted on small regularly spaced mounds about $30 \mathrm{~cm}$ high in the first season following a grassy fallow. After the sweet potato crop is harvested, winged bean or else peanut is planted into the long bed as a break crop to restore the fertility of the bed ready for another crop of sweet potato crop or in some cases a maize crop. There can be at least five plantings of sweet potato, peanuts and winged bean before land is returned to a short grassy fallow for a year or so. In some intensively cultivated parts of the Eastern Highlands Province, this cycle of rotation is continued for many years before being returned to a long fallow phase (Bourke 1988; Agricultural Systems 1101, 1115 and 1116 in Bourke et al. 2002a). A specific factor that can substantially reduce the performance of winged bean and the quality of tuber production is the presence of root-knot nematodes (Meloidogyne incognita (Kofoid and White) Chitwood), the host-specific false rust disease (Synchytrium psophocarpi (Rac.) Gäumann), leaf spot (Pseudocercospora psophocarpi (Yen) Deighton) and powdery mildew (Oidium sp.) (Price 1980). The fact that winged bean for tubers is not grown continuously but is part of a rotation may alleviate these problems.

As in Mount Hagen, the Asaro community differentiate between cultivars suitable for tubers and those for vegetable pods with their edible pre-ripe seeds; the former tending to have short pods and small leaves, while the later have more vigorous top growth, larger leaves and long fleshy pods (Figure 5). Pod-producing varieties are usually grown in mixed vegetable garden areas and house compounds. In contrast to sweet potato in which the harvest of tubers can be spread out over time according to 
need, winged bean tubers are harvested at one time and a special feast is often held on the occasion (Howlett 1962). Pig flesh, starchy root crops and a variety of leafy vegetables are steam-cooked together with the winged bean plant parts.

In recent decades coffee plantations have become important throughout the highlands. In the Eastern Highlands, peanuts were introduced as a cash crop by at least 1951 and probably as early as the 1930s (Howlett 1962; Bourke 1988). It appears that winged bean is being increasingly replaced by peanut and other introduced 'European' cash crops, especially common bean (Phaseolus vulgaris), that are easier to grow and find a ready market in the highlands and further afield (Bourke et al. 2004). In 1976, Strathern reported that in Pangia district of Southern Highlands Province, winged bean tubers were much less important than in Mount Hagen and Goroka where markets were better developed. Pangia receives more than double the annual rainfall of Mount Hagen, and sweet potato is grown without beds on composted mounds. Composting is a soil restorative practice that makes up for the lack of a legume rotation in the Pangia cropping system (Taraken and Ratsch 2009). Nevertheless, the system in Pangia is dependent on returning the land to a long fallow phase, often after just one or two crops (cf. Agricultural System 0721 in Bourke et al. 2002b).
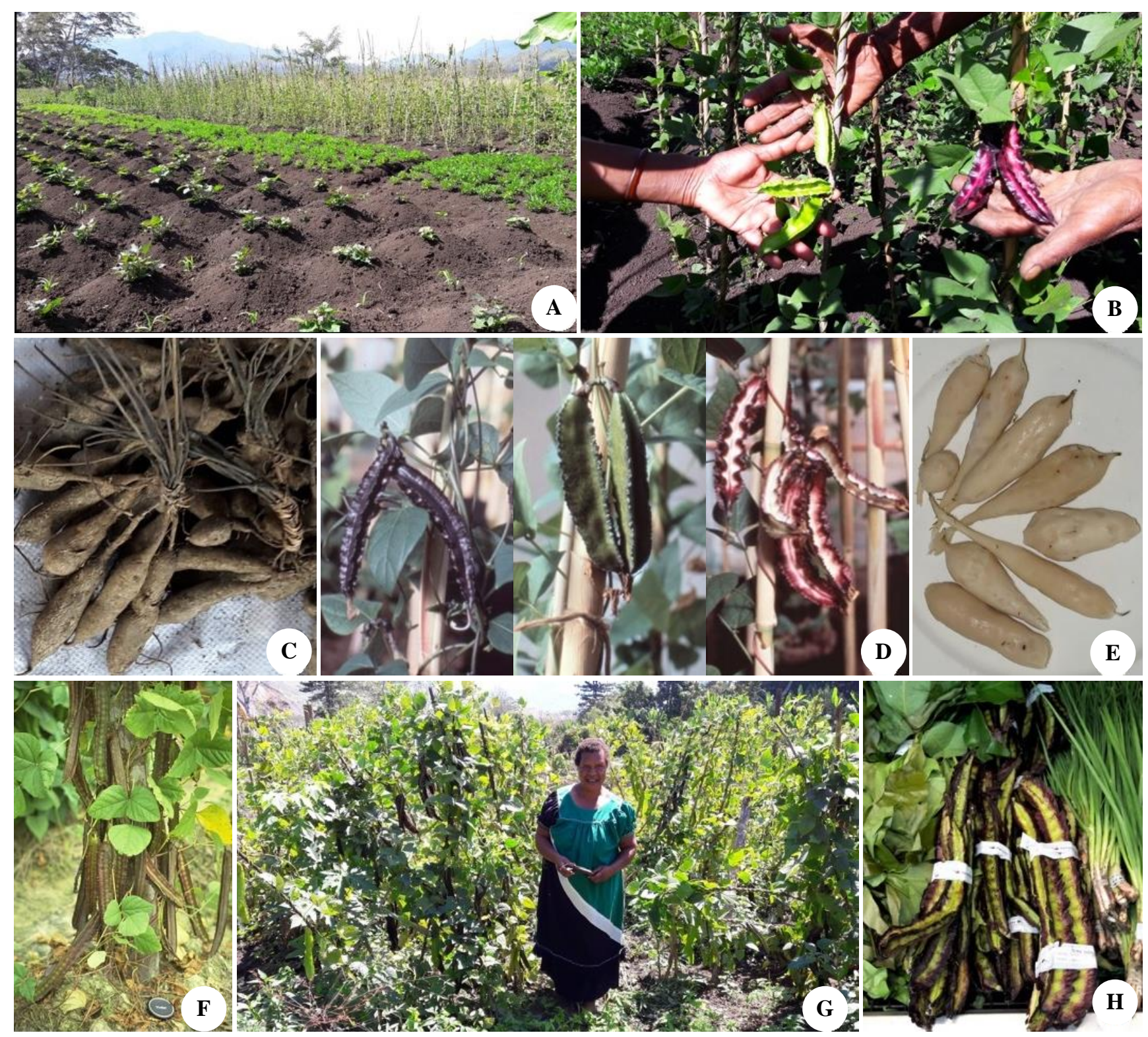

Figure 5. Winged bean in the Asaro Valley near Goroka, capital town of Eastern Highlands Province, Papua New Guinea, in 2018. A. Rotation of tuber-producing winged bean supported on canes, with long beds of groundnut and of sweet potato on mounds. B. The small pods and leaves that identify the tuberous varieties of winged beans. C. Tubers of winged bean are cooked along with sweet potatoes in a 'mumu' ground stone oven. D. Much qualitative diversity amongst tuberous cultivars. E. The outer skins of the cooked tubers are easily removed to reveal the edible tubers. F. Well-researched dual-purpose cultivar, UPS 122. G. Winged bean cultivars grown for green pods in home gardens have full-sized green seed in fleshy pods; $(\mathrm{H})$ that are sometimes sold in small amounts in urban markets 
Despite doubts raised by international research concerning the nutritional value of its tubers, the relative importance of winged bean in the cropping systems of PNG is proportional to the extent to which it is grown for tubers rather than solely for vegetable pod production. In a dietary survey in a winged bean growing area of the Wahgi Valley, Stephenson et al. (1979) weighed the components of all meals and snacks consumed by representative village families over a six-day period. It was found that at least $60 \%$ of the protein intake was provided by winged bean tubers during the time of the survey. Tubers also comprised $30-50 \%$ of the total energy consumed in the period. Nevertheless, considered across the whole year, winged bean tubers currently play only a minor, seasonal, role in the highlands (Bourke et al. 2004) and are of little significance in food security of the lowlands.

Highland and lowland tuber production were compared by Stephenson et al. $(1979,1981)$ in a genotype by environment $(\mathrm{GxE})$ evaluation of ten varieties in randomized block trials (with 5 replications per site ) at several locations varying in altitude. Individual plots were $5 \mathrm{~m}^{2}$ in size and were provided with $1 \mathrm{~m}$ high A-frame climbing supports. Averaged across sites, the dual-purpose accession, UPS 122, gave the highest tuber yield, reaching its peak yield of 11.7 t/ha at Kuk, near Mount Hagen, where " 234,800 tubers with a mean size of $50 \mathrm{~g}$ were produced per hectare". Two other varieties produced tuber yields of just over $7.5 \mathrm{t} / \mathrm{ha}$ in their optimum environments while tuber yield for all other varieties at all sites did not exceed $5 \mathrm{t} / \mathrm{ha}$. At a lowland site near Port Moresby, the best tuber yields were only $2.5 \mathrm{t} / \mathrm{ha}$.

Overall, these yields are not high compared to other PNG tuber-producing crops (Bourke 1979), however, it is important to realize that the $\mathrm{GxE}$ trials were not specifically managed for tubers (for example, the plants were not reproductively pruned, a practice that is routine in farmer-managed tuber crops in the highlands (Bala and Stephenson 1980)). A controlled environment experiment carried out by the team, demonstrated that a high temperature of $30^{\circ} / 22^{0}$ which promoted vigorous vegetative growth appeared to inhibit tuberization. The highest tuber yield was produced in a $24^{0} / 13^{\circ} \mathrm{C}$ environment. Other research teams (Rüegg 1981; Wong 1983; Okubo et al. 1992) have also shown that initiation of tuberization is favored by a lower temperature than is optimal for vegetative growth. This largely explains the difference between lowland and upland environments in the production of winged bean tubers in PNG.

\section{Country-wide analysis of Papua New Guinea farming systems}

Many of the reports concerning winged bean in New Guinea are descriptive in nature or based on reductionist experiments carried out on well-managed research station sites. A more objective assessment of the relative importance of winged bean in comparison with other legume crops incorporated in subsistence agriculture of PNG can be obtained by an analysis of data compiled by the 'Agricultural Systems of Papua New Guinea' research project (see Bourke et al. 1998). This data derives largely from surveys conducted from 1992 to 1996 (with some data dating back to the early 1980s) of all provinces in PNG. The project adopted a systematic, holistic methodology in which the presence or absence of winged bean and other food legumes was incidental to the overall goal of the project, which was "to produce information on smallholder (subsistence) agriculture at provincial and national levels". Across all nineteen provinces (Figure 6), a total of 342 agricultural systems were identified, although 55 of these were identical in character to an adjacent system across a provincial border. Thus, there was a total of 287 discrete agricultural systems defined by the project for the nation as a whole.

Table 2 summarises data relevant to the role of winged bean and other significant food legumes in the identified agricultural systems for each of the nineteen provinces. The author produced the summary by assembling the data contained in the nineteen individual provincial working papers.

Altogether, seven food legume species were listed as components of one or more of the 342 agricultural systems: winged bean (recorded in 100 of the systems); snake bean, Vigna unguiculata subsp. sesquipedalis (146 systems); common bean, Phaseolus vulgaris (136); peanut, Arachis hypogaea (94); lablab, Lablab purpureus (20); lima bean, Phaseolus lunatus (4); and pigeon pea, Cajanus cajans (2). In Table 2, only the four most significant are examined in detail.

In Eastern Highlands Province, winged bean was recorded in 20 (i.e., 83\%) of the identified agricultural systems. It was also in the Eastern Highlands that the greatest number of systems that include a legume rotation was recorded. Of the Eastern Highlands systems in which winged bean was recorded as a component, twelve (i.e., $60 \%$ ) featured rotation with a legume. Considering the central highland provinces together (Western Highlands, Chimbu and Eastern Highlands), at the time of the survey winged bean, peanut and common bean were contributing to a majority of the agricultural systems. In contrast to these three, snake bean predominated in systems at lower altitudes, where winged bean was of less importance.

Bourke (2010) has analyzed the altitudinal limits for 230 economic crops in PNG, based on a large set of comparative observational data. For winged bean he records the usual altitudinal range to be from sea level to $1900 \mathrm{~m}$. In extreme cases, winged bean may be grown up to $2070 \mathrm{~m}$. This is largely in agreement with anecdotal evidence recorded by other researchers. Bourke's estimate of the usual altitudinal range for the other three legumes are: $0-2350 \mathrm{~m}$ for common bean; $0-1850 \mathrm{~m}$ for peanut; and $0-1600 \mathrm{~m}$ for snake bean. These findings are in general agreement with the analysis presented in Table 2 . The implications of the data are that at the time of the survey in the 1990s, winged bean was still making a contribution to agricultural systems in PNG, particularly in the highlands. However, species like common bean introduced since the beginning of the colonial period in the 1870 s have made steady inroads into systems that were previously the relatively exclusive domain of winged bean (Bourke et al. 2004). The question is will winged bean continue to have a place in the agricultural systems of the future? 


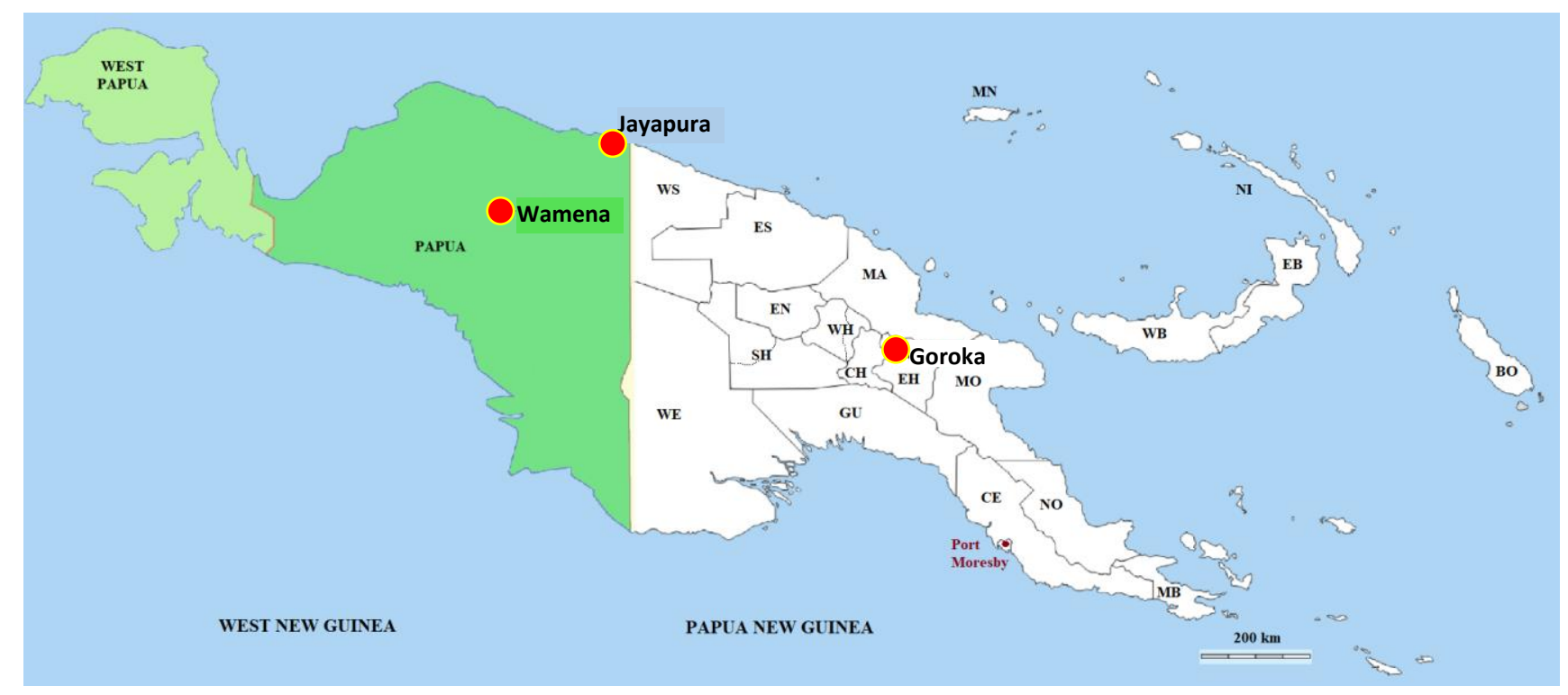

Figure 6. Map of Papua New Guinea indicating boundaries between nineteen provinces at the time of the agricultural system survey in the 1990 s

Table 2. The number of distinct agricultural systems identified within each of nineteen provinces of Papua New Guinea at the time of the Agricultural Systems project, together with characteristics of those systems particularly relating to the presence or absence of winged bean and other food legume crops. The mean altitude of all those systems within a province that include a particular legume is given, along with the number of those systems that include a legume rotation as part of the cropping sequence (Data derived from Bourke et al. (1998) and associated provincial working papers).

\begin{tabular}{|c|c|c|c|c|c|c|c|c|c|c|}
\hline \multirow{2}{*}{$\begin{array}{l}\text { Name of province } \\
\text { (map code) }\end{array}$} & \multirow{2}{*}{$\begin{array}{c}\text { No. of } \\
\text { systems }^{1}\end{array}$} & \multirow{2}{*}{$\begin{array}{c}\text { Main } \\
\text { staple } \\
\text { crop }(\mathbf{s})^{2}\end{array}$} & \multicolumn{4}{|c|}{$\begin{array}{l}\text { Mean altitude (m) of ag systems that } \\
\text { include a particular legume } \\
\end{array}$} & \multicolumn{4}{|c|}{$\begin{array}{l}\text { Number of ag systems } \\
\text { with a legume rotation }\end{array}$} \\
\hline & & & $P . v$ & $P . t$ & A. $h$ & V.u & $P . v$ & P. $t$ & A. $h$ & V.u \\
\hline Western (WE) & $16(6)$ & 3,2 & 30 & 366 & 273 & 58 & 0 & 0 & 1 & 1 \\
\hline Gulf (GU) & $14(4)$ & $3,1,2$ & 1050 & 1263 & $\mathrm{~N}$ & 41 & 0 & 0 & $\mathrm{n}$ & 0 \\
\hline Central (CE) & $22(1)$ & 2,1 & 1238 & 750 & $\mathrm{~N}$ & 214 & 1 & 0 & $\mathrm{n}$ & 4 \\
\hline Milne Bay (MB) & $30(5)$ & $1,4,5$ & $\mathrm{~N}$ & 453 & 23 & 133 & $\mathrm{n}$ & 0 & 0 & 0 \\
\hline Northern (NO & $13(4)$ & 1,2 & 800 & 539 & 340 & 388 & 0 & 0 & 0 & 0 \\
\hline Southern Highl. (SH) & $23(7)$ & $1,3,8$ & 1667 & 1140 & 1290 & $\mathrm{~N}$ & 1 & 1 & 1 & 0 \\
\hline Enga $(\mathrm{EN})$ & $13(5)$ & $1,4,8$ & 1941 & 1713 & 1238 & $\mathrm{~N}$ & 0 & 0 & 0 & 0 \\
\hline Western Highl. (WH) & $12(6)$ & $1,2,4$ & 1781 & 1617 & 1640 & $\mathrm{~N}$ & 4 & 4 & 3 & 0 \\
\hline Chimbu $(\mathrm{CH}$ & $14(7)$ & 1 & 1704 & 1792 & 1825 & $\mathrm{~N}$ & 6 & 3 & 2 & 0 \\
\hline Eastern Highl. (EH) & $24(20)$ & $1,2,4$ & 1714 & 1723 & 1554 & 1000 & 12 & 12 & 10 & 0 \\
\hline Morobe (MO) & $40(14)$ & $1,2,6$ & 1169 & 997 & 872 & 211 & 4 & 2 & 6 & 2 \\
\hline Madang (MA) & $32(11)$ & $1,4,7$ & 1154 & 609 & 904 & 412 & 0 & 0 & 2 & 2 \\
\hline East Sepik (ES) & $20(8)$ & $3,4,7$ & 481 & 236 & 300 & 189 & 0 & 1 & 1 & 1 \\
\hline West Sepik (WS) & $11(2)$ & $3,1,4$ & 1850 & 350 & $\mathrm{~N}$ & 350 & 0 & 0 & $\mathrm{n}$ & 0 \\
\hline Manus (MA) & $7(0)$ & $3,1,5$ & $\mathrm{~N}$ & $\mathrm{~N}$ & 100 & 103 & $\mathrm{n}$ & $\mathrm{N}$ & 1 & 1 \\
\hline New Ireland (NI) & $14(0)$ & $1,4,7$ & $\mathrm{~N}$ & $\mathrm{~N}$ & $\mathrm{~N}$ & 120 & $\mathrm{n}$ & $\mathrm{N}$ & $\mathrm{n}$ & 1 \\
\hline E. New Britain (EB) & $10(0)$ & $2,1,4$ & $\mathrm{~N}$ & $\mathrm{~N}$ & 200 & 217 & $\mathrm{n}$ & $\mathrm{N}$ & 3 & 3 \\
\hline W. New Britain (winged bean) & $18(0)$ & $1,4,5$ & $\mathrm{~N}$ & $\mathrm{~N}$ & $\mathrm{~N}$ & 112 & $\mathrm{n}$ & $\mathrm{N}$ & $\mathrm{n}$ & 2 \\
\hline Bougainville (BO) & $9(0)$ & 1,2 & $\mathrm{~N}$ & $\mathrm{~N}$ & 205 & 155 & $\mathrm{n}$ & $\mathrm{N}$ & 0 & 0 \\
\hline Total & 342 & & & & & & 28 & 23 & 30 & 17 \\
\hline Avg 4 & & & 1464 & 1085 & 925 & 212 & & & & \\
\hline
\end{tabular}

Notes:

${ }^{1}$ The number of agricultural systems identified within each province. (The figures in brackets are the number of these systems in which winged bean is recorded as a component crop).

${ }^{2}$ Main staple crops: the most important staple crop (in bold) along with up to two other important staples for each province

1. Sweet potato (Ipomoea batatas); 2. Banana (Musa cvs); 3. Sago (Metroxylon sagu); 4. Taro (Colocasia esculenta);

5. Cassava (Manihot esculenta); 6. Chinese taro (Xanthosoma sagittifolium); 7. Yam (Dioscorea esculenta);

8. Potato (Solanum tuberosum)

${ }^{3}$ Legume codes: P. $v=$ Common bean (Phaseolus vulgaris); $P . t=$ Winged bean (Psophocarpus tetragonolobus); A. $h=$ Peanut (Arachis hypogaea); V. $u=$ Snake bean (Vigna unguiculata);

$\mathrm{n}=$ no agricultural systems include the particular legume as a component

${ }^{4}$ The averages here are calculated across all the agricultural systems that include the particular legume species. 


\section{WITHER WINGED BEAN?}

In December 1985, the author carried out a brief survey of winged bean cultivation on the island of Bali, Indonesia. In markets in Denpasar and Ubud, small quantities of winged bean vegetable pods and green seeds were on sale. Courtyard plantings of vegetable cultivars were seen in Ubud and Mengwi. In the subak land of Tabanan up to as far as Penebel, short rows of simply trellised winged bean were frequently observed growing on paddy field bunds. Significant diversity was observed in flower colour, pod shape and length, seed colour, and in maturity characteristics (i.e., whether or not full-grown plants were flowering in December).

Three decades later, in 2016, the author repeated the survey, making street walks and market visits in Denpasar, Ubud, Bedugul, and Singaraja and travelling through the rice growing areas of Tambanan. Not a single example of winged bean in cultivation or on sale was observed. Admittedly, this was a different time of year, May rather than December. Local Balinese were quick to inform us that winged bean is still a regular food item particularly in the regencies of Gianyar and Klungkung. Nevertheless, similar anecdotal evidence is accumulating that would suggest a pattern of slow decline in other parts of Southeast Asia; for example, evidence from three separate surveys by the author of winged bean in central Myanmar (1998, 2016, and 2019) compared with the findings of Burkill (1906).

Is this apparent decline in the relevance of winged bean in traditional agricultural systems inevitable? Is it something that should concern us? What could be done to reverse this trend and what would be gained by doing so? In this section I will consider just four possible cropping system scenarios that could provide an answer to these questions. I will not focus in detail on the nutritional aspects of these scenarios which is a large topic in itself, but rather on the agronomic characteristics of four cropping systems with potential to benefit rural communities of the future.

\section{Trellised winged bean for vegetable pod production}

winged bean growth habit is invariably indeterminate. Many commentators have considered this trait to be a limitation, a trait to be overcome by plant breeding techniques if winged bean is ever to compete with mainstream food legume species (Eagleton et al. 1980; Khan 1982; Shivashankar and Reddy 1984; Jugran et al. 1986). However, this point of view, born out of the obvious success of determinate grain legume species in subhumid and semi-arid environments, overlooks the many advantages of a climbing growth habit in the wet tropics.

In Uganda and eastern Africa generally, climbing varieties of Phaseolus vulgaris consistently out-yield varieties with a bush habit (Wortmann 2001; Mcharo and Katafire 2014; Ronner et al. 2018). Rachie and Luse (1980) pointed to four likely advantages of trellis-supported indeterminate beans in the humid tropics: reduced disease and insect pressure compared to bush varieties with their short internodes and densely packed foliage; extended production time, often beneficial in subsistence farming contexts; better light interception and hence growth potential in mixed species gardens; better quality produce because pods and their seed are raised above the ground and are less subject to dampness and humidity; and a less expensive seed requirement because determinate climbing varieties can be planted at a lower plant density than is the case for determinate varieties. In considering winged bean bean specifically, the authors suggested (Rachie and Luse (1980): "few areas of investigation have more potential for intensifying production on small holdings" than research into "plant support technology".

Several research teams have demonstrated the substantial benefit in terms of pod and seed yield of trellising winged bean compared with allowing the plants to trail along the ground (Khan and Blackburn 1974 unpublished report University of Papua New Guinea; Karikari and Oteng 1977; Nangju and Baudoin 1979; Wong 1980; Banerjee et al. 1984; Schiavinato and Válio 1996a). In general, upright stakes have been less effective than trellising (Herath and Fernandez 1980; Chandrasegaram and Senanayake 1981). Employing a long-lasting trellis structure consisting of strong upright poles linked by two horizontal wires, and with raffia strung in a zigzag pattern between the wires, Wong $(1976,1980)$ obtained a cumulative green pod yield of $35 \mathrm{t} \mathrm{ha}^{-1}$ from the Malaysian accession M14/4. In a randomized block experiment, he found that trellis support increased seed yield up to ten-fold and tuber yield three-fold in comparison with plots where plants were allowed to trail along the ground. For seed yield but not for tuber yield, a 1.8-meter-high trellis out-yielded a $1.2 \mathrm{~m}$ high trellis.

The Malaysian team went on to demonstrate the potential benefits for commercial vegetable production of this kind of semi-permanent trellis structure by carrying a first crop through to 19 weeks after planting, followed by two cycles of ratooned regrowth (Motior Rahman 1998; Motior Rahman et al. 1998a,b). They achieved a cumulative seed yield of $6.26 \mathrm{t} \mathrm{ha}^{-1}$. Plants grown on the 2 $\mathrm{m}$ high trellis had faster rates of growth for plant dry matter, nodule dry matter and total nitrogen than untrellised plants. The authors explained the benefits of their trellising system primarily in terms of the higher photosynthetic efficiency of plants achieved by improved leaf display.

It is important to recognize that the benefits of trellising and ratooning apply particularly to lowland Southeast Asian vegetable-producing accessions with strong branching tendencies (Tanzi et al. 2019b). Such accessions reach maximum pod and seed yields at relatively low plant densities. With a high yielding Javanese accession, UGM1, Thompson and Haryono (1980) found that the optimum plant density for trellised green pod and dry seed yield was below 75,000 plants/ha and probably as low as 20,000 plants/ha. On the other hand, for PNG accessions such as UPS 122 (which has a much lower branching tendency), Stephenson (1980) obtained an optimum density for seed production of 150,000 plants/ha over two seasons of evaluation in Port Moresby. 
There have been major advances in systems for intensive production of vigorous indeterminate vegetable cultivars over the last few decades (Hort Innovation 2019; Peet and Welles 2018). Winged bean production systems have yet to benefit from these developments.

\section{Winged bean combined with other crops to achieve optimum Land Equivalent Ratios}

In highland New Guinea, winged bean is often grown as just one component of mixed plantings along with sweet potato, taro, corn, and vegetables like pumpkin, cucumber and amaranth (Figure 4). Around Mt Hagen, Khan et al. (1977) observed: "mixed stands of winged bean and maize appear to be very common, although in these the maize plants grow on the borders of the blocks, there being only 8-10 plants per 5-10 $\mathrm{m}^{2}$ ".

The combination of winged bean with maize as an intercrop was investigated in two significant studies in the vicinity of Peradeniya $\left(7^{0} 16^{\prime} \mathrm{N}\right.$, altitude $500 \mathrm{~m}$ asl), in the Central province of Sri Lanka in the 1980s. Gunasena and Gunathilake (1986) investigated the effects of planting either UPS 99 (a short duration winged bean from highland PNG) or SLS-47 (a vegetatively vigorous Sri Lankan accession) at three densities $(8,230 ; 12,346$; or 24,691 plants $/ \mathrm{m}^{2}$ ) in November (dry season) along with a maize composite variety planted in rows at two densities $(12,346$; or 49,383 plants $/ \mathrm{m}^{2}$ ). Mono-cropped maize at the high density was also included as a control treatment. Corn cob yield ranged from 5.0 to $7.5 \mathrm{t} / \mathrm{ha}$ but was found not to be significantly affected either by maize density or by the presence of winged bean of either accession or at any density of winged bean planting. Mean fresh winged bean pod yield was greatest at the highest density for both winged bean accessions irrespective of the density of the maize planting, and was significantly greater for SLS-47 than for UPS 99; the highest fresh pod yield of $27 \mathrm{t} / \mathrm{ha}$, and highest estimated gross financial return was obtained when SLS-47 was grown at the highest winged bean density in combination with the low maize density.

In the second study, Samaranayake and Gunasena (1986, unpublished report University of Peradeniya) examined the effect on a winged bean-maize intercrop of planting the winged bean at three different planting dates in relation to the maize planting. Maize cv 'Badra' was planted in the dry season of 1985 at two locations; and four winged bean accessions (an Indonesian accession, two contrasting Sri Lankan accessions, and TPt 1 from IITA, Nigeria) were planted either four weeks prior to the maize, two weeks prior to the maize, or simultaneously with the maize. A monocrop maize treatment and a winged bean monocrop (supported on cut Glyricidia stakes) were also included as controls. In the intercropped treatments, the winged bean was planted at 28,000 plants/ha and the maize at 83,000 plants/ha, i.e. much higher densities than in the previous experiment. In contrast to the previous experiment, the winged bean in this experiment was harvested not for vegetable pods but for dry seed, and it was found that intercropping not only reduced the grain yield of the maize (by 30-60\%) but also the winged bean seed yield (by 30-35\%). Even so, the Land Equivalent
Ratios (LERs) of the intercrops were greater than unity for all except two of the treatment combinations. The winged bean planted four weeks before the maize took between 7 and 29 more days to reach $50 \%$ flowering than did the winged bean planted simultaneously with the maize and there were differences between accessions in this. The highest grain yield for intercropped maize was obtained when the winged bean was planted simultaneously with the maize; this was the winged bean planting date for which LERs were the greatest. The highest yield obtained for winged bean in the intercrop treatments was when it was planted four weeks prior to the maize.

A different result was obtained by Hikam et al. (1991, 1992 ) in Kentucky ( $38^{0} \mathrm{~N}$ latitude), when winged bean was intercropped with maize for silage and production was assessed in terms of total above-ground biomass and nitrogen. The inoculated winged bean accession Tpt1 was grown in a 1:1 intercrop with either a short duration or long duration maize hybrid grown at three maize densities for silage production. Each tested intercrop system and maize density $\left(35,900 ; 46,500\right.$ and 47,500 plants ha $\left.^{-1}\right)$ resulted in Land Equivalent Ratios greater than unity for both dry matter yield and nitrogen yield despite the expected reductions in yields of individual crop. Intercropping the early maturing maize hybrid with winged bean resulted in $14-18 \%$ greater biomass and $39-67 \%$ greater nitrogen per hectare than the relevant maize monocrop control plots. In these trials, when final harvest of the plots took place at physiological maturity for the maize, the winged bean was still in the vegetative, climbing, non-flowering stage.

At Faisalabad in Pakistan $\left(31^{0} 25^{\prime} \mathrm{N}\right)$, when Aslam (1980) combined winged bean as an intercrop with jute the support plants lodged under the weight of the winged bean's vegetative growth and when combined with sorghum, the seed yield of the support plant was significantly reduced by competition with the winged bean as was also the case for maize in the Kentucky intercrop trials.

Thiruketheeswaran and Senanayake (1981), at Peradeniya in Sri Lanka, conducted two field experiments to study the yielding ability of winged bean grown for vegetable pod production when mixed with bush-bean and pole-bean (Phaseolus vulgaris). Three intercrop systems were tested (winged bean/bush-bean, winged bean/polebean and winged bean/bush-bean/pole-bean). Total yields of the intercrops were greater than the mono-cropped systems. In both seasons, the winged bean/pole-bean intercrop system gave the highest total pod yields $(18,456$ $\mathrm{kg} \mathrm{ha}^{-1}$ and 22,226 kg ha-1), and the highest estimated protein production (443 kg ha-1 and $533 \mathrm{~kg} \mathrm{ha}^{-1}$ ) respectively. Bush-beans had almost similar yields when grown in mixed cropped systems as when grown as a monocrop. The highest estimated gross income per season was obtained from the intercrop combining all three crops but it was not significantly different from that calculated for the winged bean/pole-bean mixed crop.

In West Java, Maure et al. (2019) have recently investigated the feasibility of a tomato/winged bean intercrop. At relatively low plant densities of either 20,000 or 28,500 plants per hectare, fertilized trellised winged bean intercropped with tomatoes at a density of up to 
20,000 plants per hectare experienced no change in phenology nor any reduction in pod size or number of pods per plant compared with monoculture winged bean at the same densities. Unfortunately, the authors gave no details regarding the performance of the tomatoes, so it is not possible to determine whether the interspecies competition resulted in an improvement in the Land Equivalent Ratio.

Also in West Java, Harjadi and Agusta (1980) studied the effect of relay planting winged bean with cassava. The cassava was grown either in monoculture or with winged bean planted at the same time or up to six weeks later. When harvested at eight months, the monocultured cassava significantly out yielded the cassava of the intercrop treatments. The best intercrop combination was achieved from plots in which the winged bean was planted two weeks after the cassava: i.e., $26 \mathrm{t} \mathrm{ha}^{-1}$ cassava and $0.45 \mathrm{tha}^{-}$ ${ }^{1}$ winged bean seed, compared with $28.6 \mathrm{t} \mathrm{ha}^{-1}$ cassava in the monoculture plots. Estimated protein yield was $458 \mathrm{~kg}$ $\mathrm{ha}^{-1}$ for the best intercrop compared with just $229 \mathrm{~kg} \mathrm{ha}^{-1}$ for the monoculture. Relay cropping with staple crops is of course an important potential use for winged bean, but the choice of cultivars and the optimal timing of the plantings is a complex research tasks that requires several seasons of evaluation for such systems to provide genuine benefits to farmers (Correia et al. 2014).

Several authors have suggested that winged bean could be grown along with living supports such as provided by the leguminous genera Leucaena, Glyricidia and Sesbania, but there have been no controlled experiments apart from the limited study reported by Nangju and Baudoin (1979) to determine the feasibility or practical management options for such regimes. In the literature, there are many arguments posed in favor of intercrop systems compared with monocrops, especially for low input unmechanized agricultural contexts. But the supposed benefits of such systems need to be tested empirically and cannot be assumed (Lal 1989).

\section{Expanded range and end-uses for winged bean tuber production}

The two main parts of the world where winged bean is grown for its tubers - central Myanmar and the highlands of PNG- differ markedly as do their cropping systems. In Myanmar, the tuber crops are grown at a latitude of $22^{\circ} 00^{\prime}$ $\mathrm{N}$ and altitude of around $75 \mathrm{~m}$ asl whereas the seed for the crop is produced $80-100 \mathrm{~km}$ to the northeast at $22^{0} 30^{\prime} \mathrm{N}$ latitude and an altitude of around $750 \mathrm{~m}$ asl. In PNG on the other hand, tubers are produced at a latitude of around $6^{0} \mathrm{~S}$ and a mean altitude of around $1,700 \mathrm{~m}$ asl, while the seed for the crop is produced in situ from selected plants within the tuber crop. Whereas, tuber crops in Myanmar are grown without staking or trellising and only limited reproductive pruning, tuber crops in PNG are always staked and pruned rigorously.

Despite these differences, research suggests that as for flowering and reproductive development, the great majority of winged bean accessions from both PNG and Southeast Asia are photo-thermal sensitive, requiring shorter daylengths and lower temperatures than is optimal for vegetative growth in order to initiate tuber formation
(Wong and Schwabe 1980; Rüegg 1981; Wong 1983; Schiavinato and Válio 1996b; Okubo et al. 1992). However, some variation between accessions has been detected in the degree of photo-thermal sensitivity; Rüegg (1981) and Okubo et al. (1990) have reported that certain winged bean accessions that have reduced daylength sensitivity for flowering, similarly are less sensitive to daylength for tuber initiation.

It is very likely that the gene-pools for tuber production in central Myanmar and highland PNG are quite different. Research exploring synergies between the two and between the cropping systems that generate the gene-pools should produce dividends not only for the traditional tubergrowing communities but also for other potential growing areas. To date, research of this kind has not been conducted, although general attempts to screen global germplasm have shown significant variation in tuber yield and protein content (de Lumen and Reyes 1982; Hettiarchchy and Sri Kantha 1982; Hildebrand et al. 1982; Adegboyega et al. 2019).

One practical issue in considering the nutritional properties of winged bean tubers compared to those of the seed is the high moisture content $(65.8 \%$; Hettiarchchy and Sri Kantha 1982). Tubers spoil within a few weeks of harvest and must be dried and processed if they are to be stored for the long term. However, the solubility (and thus the extraction) of the proteins is reduced when dried tubers are stored for some time (Kortt and Caldwell 1984).

Starch is the main carbohydrate of tubers (21.7-32.1\% on a fresh weight basis), residing in the flesh rather than the peel (Poulter 1982). Fat content of tubers is low. There has been little scientific attention paid to the content and properties of the fibre and flavor compounds, which are likely to have a bearing on the consumer acceptance of tubers of different genotypes.

As noted above, once the peel (representing around $25 \%$ of the whole winged bean tuber) is removed, and the water content and non-protein nitrogen of the remaining flesh is taken into account, the total apparent protein content of the edible portion on a dry weight basis - an average of only $5.5 \%$ in the three accessions analyzed by Poulter (1982) - may be less than what other researchers have reported. The tubers lack the higher molecular weight storage globulins found in seed cotyledons and have a greater content of low molecular weight peptides and free amino acids (de Lumen and Reyes 1982; Kortt and Caldwell 1984). While the balance of amino acids (comparable with that found in the seed) is more favorable than was suggested by some early reports, it is, as in other legumes, relatively low in sulfur-containing amino acids.

There have been a number of studies on the antinutritional components in winged bean tubers and on the effectiveness of different methods of cooking them (Rao and Belavady 1979; Shet et al. 1985, 1989; Kortt and Caldwell 1987; Habu et al. 1992). Much of the difference between reports is likely due to differences between the genotypes assessed (Hildebrand et al. 1982). The concentration of trypsin inhibitors and agglutinating lectins, especially basic lectins, is as at least as high in the roots as in the seed (Kortt and Caldwell 1987; Shet and 
Madaiah 1987). Shet et al. 1989 orally administered lectins isolated from raw tubers to rats. The result was a decline in food intake and body weight as well as deleterious changes in the mucosal epithelia of the gastrointestinal tract. Thus, it was not surprising that Rao and Belavady (1979) found that weanling rats fed diets that included uncooked tubers all died after just two weeks. Fed diets containing cooked tuber meal, rats made only modest weight gains over a three-week period - half the gains made by rats in a parallel experiment fed diets containing cooked winged bean seed or soybean seed meal. On the basis of their experience Rao and Belavady (1979) concluded "the [winged bean] tuber ... does not show any promise as a food in normal times".

From the published literature, it appears that there have been no other studies of this kind. This suggests that the above conclusion has prevailed as the last word on the topic, which is unfortunate, because it overlooks the field evidence reported above that tubers of appropriate cultivars have long been appreciated as food items in at least two centers of winged bean diversity - PNG and Myanmar. As Kortt and Caldwell (1984) expressed it, "Despite the low level of essential sulphur-containing amino acids and the high content of proteinaceous anti-nutritional factors, winged bean tubers appear to be an excellent high protein food source for the tropics. The development of the winged bean tuber ... as a food crop however, is dependent more on agronomic factors (such as variety selection, yields, ease of harvest, storage of tubers) than nutritional limitations."

To date, there have been few investigations into the field agronomy of winged bean tuber production outside the traditional growing areas Karikari (1979) in Ghana and Herath and Fernandez (1980) in Sri Lanka carried out useful experiments examining the effectiveness of staking, reproductive pruning, and planting on ridges versus planting on wide beds or on the flat. Both studies confirmed the efficacy of reproductive pruning in raising tuber yields, while only in the Ghana study did staking increase yields above planting on the flat. Quoted tuber yields $\left(830 \mathrm{~kg}\right.$ fresh tubers $\mathrm{ha}^{-1}$ in Ghana and $535 \mathrm{~kg}$ dry matter kg ha-1 in Sri Lanka) were low compared to what has been measured in PNG (Stephenson 1979). Differences in environment and agronomy are only part of the explanation for the relatively low tuber yields obtained in new test locations. In Florida, Hildebrand et al. (1982) found that out of 189 genotypes they introduced from the global collection only 38 produced tubers. The highest tuber yield they recorded was $2629 \mathrm{~kg}$ dry matter/ha from the dualpurpose PNG accession UPS 122. Genotype, environmental conditions, and cultivation practices all contribute to the considerable range in success experienced in introducing winged bean into new locations.

\section{A benign, nitrogen-rich, cover crop}

One potential non-traditional use of winged bean that is worth close scrutiny is as a cover crop, first reported in detail by Karikari $(1980,1983)$ in Ghana. In Africa and Southeast Asia, related members of Psophocarpus notably $P$. scandens, and probably $P$. palustris (with which species it has often been conflated) - have at times had extensive use as cover crops (Wulijarni-Soetjipto 1997).
Introduced initially for tea plantations (Keuchenius 1924), $P$. scandens had wide usage, especially in Sumatra after World War II, as a cover between newly planted rubber and oil palm trees (Heyne 1927; Burkill 1935). Although it was slower to establish than the more conventionally used alternatives (e.g. Centrosema spp., Pueraria spp.) with which it was combined, it eventually overgrew and outcompeted these species to provide a deep-rooted, wellnodulated, mono-crop cover, particularly on marshy, lowlying clays (Tong et al. 1961). The main limitation to its use in this context was a limited seed supply. At Ibadan in Nigeria, Psophocarpus palustris (possibly P. scandens misnamed) was compared to four commonly used leguminous cover crops for its effects on a subsequent maize/cassava intercrop. Although the effects were not statistically significant, the mean maize seed yield and cassava tuber yield ranked highest and third highest respectively after the $P$. palustris cover crop in comparison with the other four cover crops (IITA 1980 cited in Karikari 1983).

In contrast to species like $P$. scandens/palustris and the tuberous Pueraria montana var. lobata which have strong tendency to escape from cultivation and become naturalized in waste land and secondary forest (see Harron et al. 2020), there is negligible risk of winged bean becoming a nuisance weed even in its more vegetatively vigorous lowland accessions. This means that it has potential to be a useful, low-risk, cover crop in sequence with, or between, upright-growing annual crops like maize, okra and pigeon pea.

In Keravat, New Britain, Bourke (1975) tested winged bean as a cover crop alongside 22 other legume species over a period of three years. He concluded (as did Khan and Blackburn 1974, unpublished report University of Papua New Guinea) that winged bean does not produce good ground cover or much top growth and that it is not suitable as a cover crop in PNG. However, it is important to emphasize that it is very likely that the cultivar Bourke use in this study originated from PNG, and that PNG varieties in general are very different in vegetative growth characteristics to the germplasm originating from Southeast Asia (Eagleton 1985; Tanzi et al. 2019b).

In Ghana, Karikari (1983) reported successful trials with winged bean used as a cover crop in oil palm and plantain fields. In the plantain experiment, banana yields were reported to be higher where winged bean was planted at the same time between the rows without staking support than in un-weeded mono-cropped bananas. In Calcutta, Banerjee et al. (1984) grew plots of winged bean as a cover crop, un-inoculated, un-staked, under rain-fed conditions, without fertilizer and with minimum care other than occasional weeding. The plots were observed for two years through two cycles of growth, the second cycle regenerating from the tuberous base following the completion of pod production and die-back at the end of the first cycle. The authors carried out six harvest samplings over the two years and reported "protein contents of the dry matter of the whole plant, vegetable pods, seeds and tubers ... in the range 22-34, 25-30, 32-38 and $16-19 \%$, respectively". 
In field trials in Okinawa, Japan $\left(26^{\circ} \mathrm{N}, 127^{\circ} \mathrm{E}\right)$, Anugroho et al. (2010) compared the biomass production, nutrient uptake, leaf area index, and litter of un-staked winged bean with that of velvet bean (Mucuna pruriens (L.) DC.), a well-established leguminous cover crop of the tropics (see Correia et al. 2014). At week 18 after planting, the total biomass of leaf and stem \& petiole parts was in the range of $277-332 \mathrm{~g} \mathrm{~m}^{-2}$ in winged bean and 303-483 $\mathrm{g} \mathrm{m}^{-2}$ in velvet bean, but by week 30 there was no difference between the two. Winged bean podded later than the velvet bean, with leaf as a proportion of total above ground biomass and nitrogen content of all above-ground parts significantly higher in winged bean than in velvet bean at four harvest dates ranging between 12 and 30 weeks after planting. Leaves of the winged bean cover crop had a significantly lower $\mathrm{C} / \mathrm{N}$ ratio than leaves of the velvet bean. Uptake of phosphorus, potassium and magnesium were also higher in winged bean than in velvet bean. The untrellised biomass production was $30-70 \%$ lower in this subtropical location than reported by Weil and Belmont (1991) for staked winged bean in the tropical environment of Sri Lanka. However, the authors recommended winged bean as "an appropriate legume cover crop and green manure due to its longer growing period and ... ground-covering ability and high $\mathrm{N}$ input" (Anugroho et al. 2010).

The green manure potential of winged bean in Sri Lanka was demonstrated by Weil and Samaranayake (1991) who obtained unfertilized yields of maize 52-91\% higher on land previously cropped with winged bean (from which all above ground parts were harvested) compared with control plots that had previously grown maize. This result is a confirmation of the anecdotal reports of Burkill (1906) that winged bean grown for tubers in the irrigated plains of central Myanmar significantly benefited subsequent crops like sesame and sugarcane. Thompstone and Sawyer (1914 p 83) noted: "In some soils the development of bacterial nodules is extraordinary: the nodules are very large ... A very common rotation, especially in Kyaukse District, is $1^{\text {st }}$ year paddy, $2^{\text {nd }}$ year [winged bean], $3^{\text {rd }}$ year sugarcane, which is sometimes ratooned. The last crop is said to give a 50 percent better yield if preceded by a [winged bean tuber crop]". These observations have been elaborated upon by the detailed investigations of Masefield (1957, 1973), Ikram and Broughton (1980a, b) and Iruthayathas and Vlassak (1982, 1985) into winged bean's nodulation and nitrogen-fixing capacities in humid tropical soils.

Winged bean leaves contain from 4 to $5.5 \% \mathrm{~N}$ (i.e., 25 to $35 \%$ crude protein) on a dry weight basis (Senanayake and Sumanasinghe 1976; Ekpenyong and Borchers 1980; Ozekie and Martin 1980; Hildebrand et al. 1980; Ibuki et al. 1983; Banerjee et al. 1986; Alalade et al. 2016). Ibuki et al. (1983) observed that young leaves have the highest content of crude protein $(34 \%)$ of all plant parts with the exception of seed. Similarly, Bagchi et al. (1989) reported that crude protein content of leaves exceeds that of pods and of tubers, and is only surpassed by developing seeds in the pod 30-40 days after anthesis. Senanayake and Sumanasinghe (1976) analysed the protein content of the first mature leaf and the leaf subtending the fruit of eleven accessions. Across the accessions, the dry weight protein content of the first mature leaf ranged from 24.5 to $38.7 \%$, and of the leaf subtending the fruit from 22.6 to $35.4 \%$.

Young winged bean leaves and flowers are also a good source of provitamin A, vitamin C and minerals (Claydon 1980a; Cerny 1980; Harder 1992). The leaves may be stirfried as is the usual way of consuming leafy vegetables in Southeast Asia or steam-cooked as in the traditional ground stone ovens of New Guinea. However, Claydon (1981) noted that there is actually "little need to cook winged bean leaves ... 'except to bring out the flavour, as very few toxic factors ... have been established in them." He measured losses of $24 \%$ of calcium and $44 \%$ of iron that result from steaming the leaves (Claydon 1980a). There were also losses of Vitamin C (e.g., 40\% loss after stir-frying). On the other hand, Sri Kantha (1986) confirming that winged bean leaves are a very rich source of pro-Vitamin A, found that steam-blanching actually enhanced their pro-vitamin A content. Caution is required in advocating minimal cooking for leaves until more is known about the effects of differences in genotype, growing condition, and age of leaves on the levels of potential anti-nutritional factors. Hildebrand et al. (1980) noted that nitrate in winged bean foliage could reach levels higher than might be desirable for consumption by humans and livestock. Similarly, Harder (1994) reported that on acidic soils, aluminium accumulates in winged bean leaves and other parts to levels that might be detrimental to human health.

It is important to recognise that most of the reports of high crude protein content in winged bean leaves are based on Kjeldahl-N estimates and make no distinction between protein as such and small peptides, free amino acids and other small nitrogen-containing molecules. Winged bean leaves are thin like those of soybean, with only one layer of palisade mesophyll compared for example with the thicker leaves of mung bean (Franceschi and Giaquinta 1983). In winged bean, the storage proteins of the leaves are glycoproteins of relatively low molecular weight (27 and $29 \mathrm{kDa}$ ) (Klauer et al. 1996). The larger storage protein $(\sim 94 \mathrm{kDa})$ found in soybean leaves appears to be lacking in the leaves of winged bean. Because a portion of the reported crude protein in winged bean leaves is made up of low molecular weight peptides and other nitrogencontaining molecules it is likely that their protein-value for humans is lower than would be the case for ruminant livestock or as a microbial food-stock.

Yap et al. (1979), Anugruho et al. (2010) and others have reported that the leafy haulm of winged bean is potentially of high value as a ruminant feed source. In Myanmar, when tubers are harvested for market from untrellised fields of winged bean, the bundles of still-green vegetation are removed as potential livestock feed (Eagleton 1999). Fresh winged bean leaves are found to have much lower levels of anti-nutritional protease inhibitors and haemagglutinating lectins compared with seeds and tubers (Sri Kantha et al. 1978; Shet and Madaiah 1987; Habu et al. 1992). Yagi et al (1994) identified two acidic lectins in the leaves, but did not detect any basic lectins which are the principle cause of the potent agglutinating activity of mature seeds. This low level of 
anti-nutritional factors coupled with the high crude protein means that winged bean leaves are a potential feedstock.

Concentrates extracted from the thin leaves of winged bean have been found to be of high nutritional value. Cheeke et al. (1980) compared winged bean leaf concentrate with concentrates extracted from leaves of seven common tropical legume species and found that the winged bean concentrate had a protein efficiency ratio when fed to rats, second in value only to Clitoria ternata $\mathrm{L}$. Kailasapathy and Sandrasegaram (1983) reported that concentrates extracted from winged bean leaves contained on a dry weight basis $59.7 \%$ crude protein, $5.13 \%$ crude fibre, $10.41 \%$ ash and $0.71 \%$ crude fat. The leaf concentrate contained a modest level of trypsin inhibitor activity that could be deactivated by heat treatment for twenty minutes.

Banerjee et al (1986) in their extracting protocol obtained a much higher protein content of $62-85 \%$ along with $4.6-12.8 \%$ fat, $0.2-4.6 \%$ ash $34.2-43.7 \mathrm{mg} 100 \mathrm{~g}-1$ Bcarotene but negligible fibre $(0.5-2.7 \%)$. After protein extraction, the residual deproteinised juice proved to be an "ideal" growth medium for the protein-rich biomass production by microbes such as the filamentous fungi. They concluded: "The composition of extracted leaf proteins prepared from the vegetable tops of the winged bean, offer great potential for incorporation into food and feed products. ... Moreover, the deproteinised juice can be used for [microbial] production of protein rich biomass".

\section{CONCLUDING REMARK}

This review of traditional agricultural systems that incorporate winged bean (Psophocarpus tetragonolobus (L.) DC.) has confirmed the small but varied contribution that this high-protein legume crop has made to food security in Southern Asia and Melanesia. Focussing on tuber production in central Myanmar and highland New Guinea, and on vegetable pod production in Southeast Asia, lessons with global significance have been learned from the way subsistence farmers have grown and utilised winged bean. Research since the 1970s, building on this traditional knowledge has identified four areas where winged bean could contribute to modern agricultural systems: (i) for commercial vegetable pod production from efficiently trellised, ratooned, climbing cultivars; (ii) as a multi-purpose intercrop in low-input systems based on C-4 grain crops like maize and sorghum; (iii) as a protein-rich tuber crop either alone or in combination with starchy root crops like sweet potato and cassava (iv) as an environmentally safe, cover and forage crop in rotation with crops that benefit from its reliable nodulation and nitrogen fixing ability. The possibility of winged bean being used for its dry seed, though a worthy goal, is a more distant prospect given the competition it would face from established pulse and grain legume crops, and the fact that traditional agricultural systems appear not to have developed cultivars or efficient ways for processing and consuming dry seed.
The history of the last 50 years of efforts to convert this minor leguminous vegetable into a more significant component in our global agricultural toolkit is an object lesson not only for those who would seek to reverse the trend in declining world-wide agricultural diversity but also for those who would argue that biodiversity conservation in the broader sense is justified by the potential benefits that lie undiscovered in our diminishing floral heritage.

\section{ACKNOWLEDGEMENTS}

The author is grateful to Chai Nyet Fah and Tanveer Khan for their dedicated assistance and advice over the more than four decades of his obsession with winged beans. The author also sincerely thanks staff of the Australian Volunteer Program (AVP) who have supported him on the various assignments in Southeast Asia that have enabled the observations reported in this paper.

\section{REFERENCES}

Adegboyega T, Abberton MT, AbdelGadir AAH, Dianda M, MaziyaDixon B, Oyatomi OA, Ofodile S, Babalola OO. 2019. Nutrient and antinutrient composition of winged bean (Psophocarpus tetragonolobus (L.) DC.) seeds and tubers. J Food Quality. DOI:10.1155/2019/3075208.

Alalade JA, Akinlade JA, Aderinola OA, Fajemisin AN, Muraina TO, Amoo TA. 2016. Proximate, mineral and anti-nutrient contents in Psophocarpus tetragonolobus (L) DC. (winged bean) leaves. J Pharm Res Intl 10 (2): 1-7. DOI: 10.9734/BJPR/2016/22087.

Allen MG. (2005). The evidence for sweet potato in island Melanesia. In: Ballard C, Brown P, Bourke RM, Harwood T (eds) The Sweet Potato in Oceania: A Reappraisal. Oceania Monograph 56. University of Sydney, Sydney.

Anugroho F, Kitou M, Kinjo K, Kobashigawa N. 2010. Growth and nutrient accumulation of winged bean and velvet bean as cover crops in a subtropical region. Plant Prod Sci 13 (4): 360-366. DOI: 10.1626/pps.13.360.

Aslam M. 1980. Preliminary studies on the cultivation of winged bean in Pakistan. In: The Winged Bean. Papers presented in the 1st International Symposium on Developing the Potentials of the Winged Bean, Manilla, 1978. PCARR, Los Baños, Philippines.

Axelson L, Cassidy CM, Colon MD de, Hacklander EH, Neruda GS, Rawlings KE. 1983. Consumption and use of the winged beans by Sri Lankan villagers. Ecol Food Nutr 12 (3): 127-137. DOI: 10.1080/03670244.1982.9990708.

Bagchi DK, Banerjee A, Sasmal BC. 1989. Studies on plant growth and pod development in the winged bean Psophocarpus tetragonolobus (L.) DC. Trop Agric (Trinidad) 66 (3): 240-242.

Bala AA, Stephenson RA. 1980. The genetics and physiology of tuber production in winged beans. In: The Winged Bean. Papers presented in the 1st International Symposium on Developing the Potentials of the Winged Bean, Manilla, 1978. PCARR, Los Baños, Philippines.

Banerjee A, Bagchi DK, Si LK.1984. Studies on the potential of winged bean as a multipurpose legume cover crop in tropical regions. Exp Agric 20: 297-301. DOI: 10.1017/S001447970001797X.

Banerjee A, Chanda S, Sasmal BC and Bagchi DK. 1986. Studies on yield, extracted leaf protein and deproteinised extract of winged bean grown as a biennial crop. J Sci Food Agric 37: 783-790. DOI: 10.1002/jsfa.2740370811.

Blanco M. 1837. Dolichos tetragonolobus. Flora de Filipinas. Manila.

Bourke RM. 1975. Evaluation of leguminous cover crops at Keravat, New Britain. Papua New Guinea Agric J 1: 1-9.

Bourke RM. 1979. Root crops in Papua New Guinea. In: Belen EH, Villaneuva M (eds) Proceedings of the Fifth International Symposium on Tropical Root and Tuber Crops. PCARR, Los Banos, Philippines 17-21 September 1979. International Society of Tropical Root Crops, Los Banos, Philippines. 
Bourke RM. 1988. Taim Hangre: Variation in Subsistence Food Supply in the Papua New Guinea Highlands. [Dissertation]. Australian National University, Canberra.

Bourke RM. 2009. History of agriculture in Papua New Guinea. In: R.M Bourke and T. Harwood (eds) Food and Agriculture in Papua New Guinea. Australian National University Press, Canberra.

Bourke RM. 2010. Altitudinal Limits of 230 Economic Crop Species in Papua New Guinea. In: Haberle SG, Stevenson J, Prebble M (eds.) Altered Ecologies: Fire, Climate and Human Influence on Terrestria Landscapes. Terra Australia 32. Australian National University Press, Canberra. DOI: 10.22459/TA32.11.2010.27.

Bourke RM, Allen B, Hobsbawn P, Conway J. 1998. Agricultural Systems of Papua New Guinea. Working Paper No. 1 (Introduction to 19 provincial working papers). Australian National University, Canberra.

Bourke RM, Allen BJ, Hide RL, Fritsch D, Grau R, Hobsbawn P, Lowes E, Stannard D. 2002a. Eastern Highlands Province. Agricultural Systems of Papua New Guinea, Working Paper No. 8. Australian National University, Canberra.

Bourke RM, Allen BJ, Hide RL, Fritsch D, Grau R, Hobsbawn P, Konabe B, Levett MP, Lyon S, Varvaliu A. 2002b. Southern Highland Province. Agricultural Systems of Papua New Guinea, Working Paper No. 11. Australian National University, Canberra.

Bourke RM, Camarotto C, D'Souza EJ, Nema K, Tarepe TN, Woodhouse S. 2004. Production Patterns of 180 Economic Crops in Papua New Guinea. Australian National University, Canberra.

Brass LJ. 1941a. Stone age agriculture in New Guinea. Geograph Rev 31 (4): 555-569. DOI: $10.2307 / 210499$.

Brass LJ. 1941b. The 1938-39 expedition to the Snow Mountains, Netherlands New Guinea. Journal of the Arnold Arboretum 22: 297 342 .

Breon N. 1820. Dolichos tetragonolobus. In: Catalogue des Plantes Cultivées au Jardin Botanique et de Naturalisation de Ile Bourbon, Saint-Denis, Ile Bourbon: Impr. du Gouvernement, Saint-Denis, Ile Bourbon.

Burkill IH. 1906. Goa beans in India. Agric Ledger 4: 101-114.

Burkill IH. 1935. Psophocarpus, Neck. In: A Dictionary of the Economic Products of the Malay Peninsula, Volume 2. (1966 edition), Kuala Lumpur Malaysia.

Černý K. 1980. Comparative nutritional and clinical aspects of the winged bean. In: The Winged Bean. Papers presented in the 1st International Symposium on Developing the Potentials of the Winged Bean, Manilla, 1978. PCARR, Los Baños, Philippines.

Černý K, Addy HA. 1973. The winged bean (Psophocarpus palustris Desv.) in the treatment of kwashiorkor. Br J Nutr 29 (1): 105-112. DOI: $10.1079 / \mathrm{BJN} 19730082$

Černý K, Hoa DQ, Dinh NK, Zalena H. 1981.The winged bean seeds as a major source of protein in the diet of small children. Unpublished paper presented in the 2nd International Symposium on Developing the Potentials of the Winged Bean. Colombo, Sri Lanka, January 1981. Abstracted in The Winged Bean Flyer (Agricultural Information Bank for Asia), Laguna, Philippines) 3 (2): 31-32.

Chandel KPS, Pant KC, Arora RK. 1984. Winged Bean in India. NBPGR Sci Monogr. No. 8. National Bureau of Plant Genetics Resources, New Delhi.

Chandrasegaram S, Senanayake YDA.1981. A study on the reproductive load of winged bean Psophocarpus tetragonolobus (L.) DC. The 2nd International Symposium on Developing the Potentials of the Winged Bean. Colombo, Sri Lanka, January 1981. Abstracted in The Winged Bean Flyer (Agricultural Information Bank for Asia), Laguna, Philippines) 3 (2): 15.

Chappell MJ, LaValle LA. 2011. Food security and biodiversity: can we have both? An agroecological analysis. Agric Hum Values 28: 3-26. DOI:10.1007/s10460-009-9251-4.

Cheeke PR, Telek L, Carlsson R, Evans JJ. 1980. Nutritional evaluation of leaf protein concentrates prepared from selected tropical plants. Nutr Rep Intl 22 (5): 717-721.

Chomchalow N, Suputtitada S, Peyachoknagul S. 1980. Genetic diversity of winged bean in Thailand: a preliminary report. In: The Winged Bean. Papers presented in the 1st International Symposium on Developing the Potentials of the Winged Bean, Manilla, 1978 PCARR, Los Baños, Philippines.

Claydon A. 1975. A review of the nutritional value of the winged bean Psophocarpus tetragonolobus (L.) DC. with special reference to Papua New Guinea. Sci New Guinea 3 (2): 103-114.

Claydon A. 1979. How important a food is winged bean in Papua New Guinea. Sci New Guinea 6: 144-153.
Claydon A. 1980a. The role of the winged bean in human nutrition. In: The Winged Bean. Papers presented in the 1st International Symposium on Developing the Potentials of the Winged Bean, Manilla, 1978. PCARR, Los Baños, Philippines.

Claydon A. 1980b. Winged bean in Southern Asia. In: The Winged Bean. Papers presented in the 1st International Symposium on Developing the Potentials of the Winged Bean, Manilla, 1978. PCARR, Los Baños, Philippines.

Claydon A. 1981. Winged bean - the vegetable food. The 2nd International Symposium on Developing the Potentials of the Winged Bean. Colombo, Sri Lanka, January 1981. Abstracted in The Winged Bean Flyer (Agricultural Information Bank for Asia), Laguna, Philippines) 3 (2): 32

Claydon A. 1983. Potential of winged bean pods and their products in Papua New Guinea. Qual Plant Foods Hum Nutr 32: 167-177. DOI:10.1007/BF01091337.

Correia MV, Pereira LCR, de Almeida L, Williams RL, Freach J, Nesbitt H, Erskine W. 2014. Maize-mucuna (Mucuna pruriens (L.) DC) relay intercropping in the lowland tropics of Timor Leste. Field Crops Res 156: 272-280. DOI: 10.1016/j.fcr.2013.10.011

de Lumen BO, Reyes PS. 1982. Chemical composition studies on winged bean (Psophocarpus tetragonolobus) tubers. J Food Sci 47 (3): 821824. DOI: $10.1111 / \mathrm{j} .1365-2621.1982 . t b 12723 . x$

Eagleton GE. 1985. Evaluation of Genetic Resources in the Winged Bean (Psophocarpus tetragonolobus (L.) DC.) and their Utilisation in the Development of Cultivars for Higher Latitudes. [Dissertation]. University of Western Australia, Perth.

Eagleton GE. 1999. Winged bean in Myanmar revisited. Economic Botany 53: 342-352. DOI: 10.1007/BF02866646.

Eagleton GE. 2019. Prospects for developing an early maturing variety of Winged Bean (Psophocarpus tetragonolobus) in Bogor, Indonesia. Biodiversitas 20 (11): 3142-3152. DOI:10.13057/biodiv/d201106.

Eagleton GE, Halim AH, Chai NF. 1980. Towards the effective utilisation of winged bean germplasm. In: Proceedings of Legumes in the Tropics, Universiti Pertanian Malaysia, Selangor, Malaysia.

Ekpenyong TE, Borchers RL. 1980. Nutritional aspects of the winged bean. In: The Winged Bean. Papers presented in the 1st International Symposium on Developing the Potentials of the Winged Bean, Manilla, 1978. PCARR, Los Baños, Philippines.

Eng J. 1985. Winged bean in Irian Jaya: responses to a questionnaire. The Winged Bean Flyer (Agricultural Information Bank for Asia, Laguna, Philippines) 5 (2): 51-57.

Erskine W. 1981. Heritability and combining ability of vegetative and phenological characters of winged beans (Psophocarpus tetragonolobus (L.) DC. J Agric Sci 96: 503-508. DOI: $10.1017 /$ S0021859600034456.

Erskine W, Kesavan V. 1982. Genetic variability in the green pod production of winged bean. J Hortic Sc 57 (2): 209-213. DOI: 10.1080/00221589.1982.11515042.

Erskine W, Khan TN. 1980. Variation within and between land races of winged bean (Psophocarpus tetragonolobus (L.) DC.). Field Crops Res 3: 359-364. DOI: 10.1016/0378-4290 (80)90041-6.

Evans IM, Boulter D, Eaglesham ARJ and Dart PJ. 1977. Protein content and protein quality of tuberous roots of some legumes determined by chemical methods. Qualitas Plantarum 27 (3/4): 275-285.

Fatihah NHN, Maxted N, Rico Arce L. 2012. Cladistic analysis of Psophocarpus Neck. Ex DC. (Leguminosae, Papilionoideae) based on morphological characters. S A J Bot 83: 87-88. DOI:10.1016/j.sajb.2012.07.010.

Franceschi VR, Giaquinta RTR. 1983. Specialized cellular arrangements in legume leaves in relation to assimilate transport and compartmentation: comparison of the paraveinal mesophyll. Planta 159 (5): 415-422. DOI: 10.1007/BF00392077

Gandjar I. 1980. Fermentation of winged bean seeds. In: The Winged Bean. Papers presented in the 1st International Symposium on Developing the Potentials of the Winged Bean, Manilla, 1978. PCARR, Los Baños, Philippines.

Graham J. 1839. Psophocarpus tetragonolobus. In: A Catalogue of the Plants Growing in Bombay and its Vicinity. Government Press, Bombay.

Gunasena HPM and Gunathilake HAJ. 1986. A study on the maizewinged bean intercrop system. Coconut Research Institute Repository, Sri Lanka.

Habu Y, Peyachoknagul S, Umemoto K, Sakata Y, Ohno T. 1992. Structure and regulated expression of Kunitz chymotrypsin inhibitor genes in winged bean (Psophocarpus tetragonolobus (L.) DC.). J 
Biochem

111: 10.1093/oxfordjournals.jbchem.a123745

Handayani T, Kusmana, Liferdi, Hidayat IM. 2015. Karakterisasi morfologi dan evaluasi daya hasil sayuran polong kecipir (Psophocarpus tetragonolobus (L.) DC.). J Hortikultura. 25 (2): 126132. [Indonesian] DOI: 10.21082/jhort.v25n2.2015.p126-132.

Haq N. 1982. Germplasm resources, breeding and genetics of the winged bean of winged bean. Z Pflanzenzucht $88: 1-12$.

Harder DK. 1992. Temporal mineral allocation in plants of the cultivated winged bean (Psophocarpus tetragonolobus (L.) DC. : nitrogen and calcium. In: Sorensen $M$ (ed.) Proc of the 1st International Symposium on Tuberous Legumes, Guadeloupe. Jordbrugsforlaget, Copenhagen.

Harder DK. 1994. Aluminum contents of the edible portions of the winged bean, Psophocarpus tetragonolobus (L.) DC. (Fabaceae): field study and caveat. Plant Foods Hum Nutr 45: 127-137. DOI: 10.1007/BF01088470.

Harder DK, Smartt J. 1992. Further evidence on the origin of the cultivated winged bean, Psophocarpus tetragonolobus (L.) DC. (Fabaceae): chromosome numbers and the presence of a host-specific fungus. Econ Bot 46 (2): 187-191. DOI: 10.1007/BF02930637.

Harjadi SS, Agusta F. 1980. The effect on growth and yield of cassava plants by intercropping winged bean on different planting dates. Jurnal Agronomi Indonesia. 1980: 11-13.

Harron P, Joshi O, Edgar CB, Paudel S, Adhikari A. 2020. Predicting kudzu (Pueraria montana) spread and its economic impacts in timbe industry: a case study from Oklahoma. PloS one 15 (3): e0229835. DOI: 10.1371/journal.pone.0229835.

Hasskarl JK. 1848. Psophocarpus tetragonolobus. In: Plantae Javanicae Rariores, A. Foerstner, Berlin.

Heider KG. 1970. The Dugum Dani: A Papuan Culture in the Highlands of West New Guinea. Aldine, Chicago.

Henry CJK, Donachie PA, Rivers JPW. 1985. The winged bean. Will the wonder crop be another flop? Ecol Food Nutr 16 (4): 331-338. DOI 10.1080/03670244.1985.9990872.

Herath HMW, Dharmawansa EMP, Ormrod DP. 1980. Some growth characteristics of indigenous and introduced selections of winged beans. In: The Winged Bean. Papers presented in the 1st International Symposium on Developing the Potentials of the Winged Bean, Manilla, 1978. PCARR, Los Baños, Philippines.

Herath HMW, Fernandez 1980. Effect of cultural practices on the yield of seed and tubers in winged bean. In: The Winged Bean. Papers presented in the 1st International Symposium on Developing the Potentials of the Winged Bean, Manilla, 1978. PCARR, Los Baños, Philippines.

Hettiarachchy NS and Sri Kantha S. 1982. Studies on the nutritive value of winged bean Psophocarpus tetragonolobus L. DC. Nutrisyon (Philippines) 7 (1): 40-51.

Heyne K. 1927. Psophocarpus tetragonolobus. In: De Nuttige Planten van Nederlandsch Indie. Vol. 2. 2nd rev ed. Department van Landbouw, Nijverheid and Handel, Batavia. [Dutch]

Hide RL, Bourke RM, Allen BJ, Fritsch D, Grau R, Hobsbawn P, Lyon S. 2002. Western Highlands Province. Agricultural Systems of Papua New Guinea, Working Paper No. 10, Dept. Human Geography, Australian National University, Canberra.

Hikam S, MacKown CT, Poneleit CG, Hildebrand DF. 1991. Growth and $\mathrm{N}$ accumulation in maize and winged bean as affected by $\mathrm{N}$ level and intercropping. Ann Bot 68: 17-22. DOI: 10.1093/oxfordjournals.aob.a088213.

Hikam S, Poneleit CG, MacKown CT, Hildebrand DF. 1992 Intercropping of maize and winged bean. Crop Sci 32: 195-198. DOI: 10.2135/cropsci1992.0011183X003200010040x.

Hildebrand DF, Chaven C, Hymowitz T, Bryan HH. 1980. Variation in protein and nitrate content of vegetative growth of winged bean. Commun Soil Sci Plan 11 (12): 1195-1201. DOI 10.1080/00103628009367116.

Hildebrand DF, Chaven C, Hymowitz T, Bryan HH. 1982. Variation in storage root protein content in winged beans, Psophocarpus tetragonolobus (L.) DC. Trop Agric 59 (1): 59-61.

Hort Innovation. 2019. Greenhouse Cucumber Production. National Vegetable Extension Network, NSW, Australia.

Howlett DR. 1962. A Decade of Change in the Goroka Valley, New Guinea: Land Use and Development in the 1950s. [Dissertation]. Australian National University, Canberra.
Ibuki F, Kotaru M, Kan KK, Ikeuchi T, Kanamori M. 1983. Chemical composition of winged bean (Psophocarpus tetragonolobus) varieties. J Nutr Sci Vitaminol (Tokyo) 29: 621-629.

Ikram A, Broughton WJ. 1980a. Rhizobia in tropical legumes. VII. Effectiveness of different isolates on Psophocarpus tetragonolobus (L.) DC. Soil Biol Biochem 12: 77-82. DOI: 10.1016/0038-0717 (80)90105-4.

Ikram A, Broughton WJ. 1980b. Rhizobia in tropical legumes. IX. Pot and field trials with inoculants for Psophocarpus tetragonolobus (L.) DC. Soil Biol Biochem 12: 203-20 DOI: 10.1016/0038-0717 (80)90063-2

Iruthayathas EE, Vlassak K. 1982. Symbiotic specificity in nodulation and nitrogen fixation between winged bean and Rhizobium. Sci Hortic 16: 313-322. DOI: 10.1016/0304-4238 (82)90030-9.

Iruthayathas EE, Vlassak K. 1985. Competition between winged bean Psophocarpus tetragonolobus (L.) DC. strains for nodulation. Z Pflanzenernähr Bodenk 148: 536-543. DOI: 10.1002/jpln.19851480510.

Jalani BS, Wong KC. 1980. Research status and uses of winged bean in Malaysia. In: The Winged Bean. Papers presented in the $1 \mathrm{st}$ International Symposium on Developing the Potentials of the Winged Bean, Manilla, 1978. PCARR, Los Baños, Philippines.

Jugran HM, Nath P, Banerji BK, Datta SK. 1986. Gamma-ray induced dwarf mutant of winged bean. J Nucl Agric Biol 15 (3): 175-178.

Kailasapathy K, Sandrasegaram C. 1983. Preliminary studies on winged bean leaf protein concentrate. Sri Lankan Assoc Adv Sci, Colombo.

Karikari SK. 1979. The potential of the winged bean Psophocarpus tetragonolobus (L.) DC. as a root crop. In: Belen EH, Villaneuva M (eds) Proc Fifth International Symposium on Tropical Root and Tuber Crops. PCARR, Los Baños, Philippines 17-21 Sept 1979. International Society of Tropical Root Crops. pp 135-145.

Karikari SK. 1980 An integrated approach toward agronomic and other research needs on winged bean - a case study of winged bean collaborative programme in Ghana. In: The Winged Bean. Papers presented in the 1st International Symposium on Developing the Potentials of the Winged Bean, Manilla, 1978. PCARR, Los Baños, Philippines.

Karikari SK. 1983. Agronomic aspects in relation to plant parts in winged bean (Psophocarpus tetragonolobus (L.) DC.). Unpublished monograph, presented at the ICIPE Foundation/International Dambala Institute Conference on the winged bean. University of Agriculture, Wageningen, Netherlands, 28-29 March 1983. Abstracted in The Winged Bean Flyer (Agricultural Information Bank for Asia), Laguna, Philippines) 5 (1): 26

Karikari SK, Oteng S. 1977. The effect of staking on the growth and yield of the winged bean (Psophocarpus tetragonolobus (L.) DC.). IV Africa Symposium on Horticultural Crops. Acta Hortic 53: 159-164. DOI: 10.17660/ActaHortic.1977.53.21.

Khan TN. 1976. Papua New Guinea: A centre of diversity in winged bean (Psophocarpus tetragonolobus (L.) DC.). Euphytica 25: 693-705. DOI: $10.1007 / \mathrm{BF} 00041608$

Khan TN. 1982. Winged Bean Production in the Tropics. FAO Plant Production and Protection Paper 38. FAO, Rome.

Khan TN. 1993. Psophocarpus tetragonolobus (L.) DC. In: Siemonsma JS, Kasem Piluek (eds) PROSEA Plant Resources of South-East Asia. No. 8. Vegetables. Pudoc, Wageningen.

Khan TN, Bohn JC, Stephenson RA. 1977. Winged beans: cultivation in Papua New Guinea. World Crops and Livestock 29: 208-214.

Khan TN, Erskine W. 1978. The adaptation of winged bean (Psophocarpus tetragonolobus (L.) DC.) in Papua New Guinea. Aust J Agric Res 29 (2): 281-289. DOI: 10.1071/AR9780281.

Keuchenius AAMN.1924. Botanische Kenmerken en Cultuurwaarde als Groenbemester van een 60-tal Nieuwe Soorten van Leguminosen. Department van Landbouw, Nijverheid en Handel. Mededeelingen van het Proefstation voor Thee, No. 90, Batavia. [Dutch]

Khoury CK, Bjorkman AD, et al. 2014. Increasing homogeneity in global food supplies and the implications for food security. Proc Natl Acad Sci 111 (11): 4001-4006. DOI: 10.1073/pnas.1313490111

Khoury CK, Achicanoy AH, et al. 2016. Origins of food crops connect countries worldwide. Proc $\mathrm{R}$ Soc $\mathrm{B}$ 283: 20160792. DOI: 10.1098/rspb.2016.0792

Klauer SF, Franceschi VR, Ku MSB, Zhang DZ.1996. Identification and localization of vegetative storage proteins in legume leaves. Am. J. Bot. 83 (1): 1-10. DOI: 10.2307/2445947.

Koenig JG. 1894. Dolychos with a winged pod, 25 September 1778. Journal of a Voyage from India to Siam and Malacca in 1779. Journal of the Straits Branch of the Royal Asiatic Society 26: 58-201. 
Kortt AA, Caldwell JB. 1984. Characteristics of the proteins of the tubers of winged bean (Psophocarpus tetragonolobus (L.) DC.). J Sci Food Agric 35 (3): 304-313. DOI: 10.1002/jsfa.2740350310.

Kortt AA, Caldwell JB. 1987. Isolation and properties of the lectins from the tuberous roots of winged bean Psophocarpus tetragonolobus (L.) DC. J Sci Food Agric 39 (1): 47-57. DOI: 10.1002/jsfa.2740390106.

Kuswanto K, Ardiarini NR, Saptadi D, Waluyo B. 2016. Evaluation and selection on local strains of winged bean in Brawijaya University Indonesia. Transactions of Persatuan Genetik Malaysia 3: 51-55.

Lal R. 1989. Potential of agroforestry as a sustainable alternative to shifting cultivation: concluding remarks. Agrofor Syst 8 (3): 239-242. DOI: 10.1007/BF00129651.

Lam HJ. 1922. Psophocarpus tetragonolobus DC. p 324 In: Iets over de botanische resultaten van de Noord-Nieuw-Guinea-Expeditie 1920. Teysmannia 7-8: 289-326. [Dutch]

Lam HJ. 1945. Observations of a Naturalist in Netherlands New Guinea Perry LM (trans.). Fragmenta Papuana 5. Sargentia, Harvard.

Lepcha P, Egan AN, Doyle JJ, Sathyanarayana N. 2017. A review on current status and future prospects of winged bean (Psophocarpus tetragonolobus) in tropical agriculture. Plant Foods Hum Nutr 72 225-235. DOI: 10.1007/s11130-017-0627-0.

Loureiro de J. 1790. Dolichos tetragonolobus. In: Flora Cochinchinensis: Lisbon.

Mamicpic NG and Movillon MM. 1980. Collection, evaluation and conservation of winged bean germplasm in the Philippines. In: The Winged Bean. Papers presented in the 1st International Symposium on Developing the Potentials of the Winged Bean, Manilla, 1978 PCARR, Los Baños, Philippines.

Masefield GB. 1957. The nodulation of annual leguminous crops in Malaya. Empire J Exp Agric. 25 (98): 139-150.

Masefield GB. 1973. Psophocarpus tetragonolobus - a crop with a future? Field Crop Abstracts 26 (4): 157-160.

Masefield GB. 1985. Letter to the Editor. The Winged Bean Flye (Agricultural Information Bank for Asia, Laguna, Philippines) 5 (2): 3 .

Maure GH, Chozin MA, Santosa E. 2019. The effect of population density and intercropping with tomato on the growth and yield of winged bean (Psophocarpus tetragonolobus). J Tropical Crop Science (Indonesia) 6 (2): 81-88.

Mcharo M, Katafiire M. 2014. How ASARECA's Climbing Bean Project Has Improved Livelihoods in Rwanda, Burundi and Eastern DR Congo. ASARECA, Butare, Rwanda.

Merrill ED. 1910. Psophocarpus Neck. An enumeration of Philippine Leguminosae with keys to the genera and species. Phil J Sci 5 (1): 136.

Miklouhu-Maclay N de. 1885. Plants in use by the native of new Guinea. Proc Linn Soc NSW 10 (3): 348, 358

Motior Rahman M. 1998. Physiological Response of Winged Bean (Psophocarpus tetragonolobus (L.) DC.) to Support Systems and Ratooning. [Dissertation]. Universiti Putra Malaysia, Selangor, Malaysia.

Motior Rahman M, Wan Mohamad WO, Wong KC, Shamsuddin ZH 1998a. Physiological studies of ratooned and non-ratooned winged bean grown with and without support. In: Proceedings of the $9^{\text {th }}$ Australian Agronomy Conference, Wagga Wagga, Australia.

Motior Rahman M, Wan Mohamad WO, Wong KC, Shamsuddin ZH 1998b. Nitrogen accumulation and partitioning by winged bean in response to support systems. Expl Agric 34 (1): 41-53. DOI: 10.1017/S0014479798001045.

Nangju D, Baudoin JP. 1979. Performance of winged bean (Psophocarpus tetragonolobus (L.) DC.) in Nigeria. J Hortic Sci 54 (2): 129-136. DOI: $10.1080 / 00221589.1979 .11514860$.

NAS. 1975. Underexploited Tropical Plants with Promising Economic Value. Board of Science and Technology for International Development. National Academy of Sciences, Washington DC.

NAS. 1981. The Winged Bean: A High-Protein Crop for the Humid Tropics, 2nd ed. National Academy of Sciences, Washington DC.

Okezie BO, Martin FW. 1980. Chemical composition of dry seeds and fresh leaves of winged bean varieties grown in the U.S. and Puerto Rico. J Food Sci 45 (4): 1045-1051. DOI: 10.1111/j.1365 2621.1980.tb07509.x

Okubo H, Fujieda K, Uemoto S. 1990. Recent progress in winged bean research. Trop Agric Res Ser 23: 167-173.

Okubo H, Masunaga T, Yamashita H, Uemoto S. 1992. Effects of photoperiod and temperature on tuberous formation in winged bean
(Psophocarpus tetragonolobus). Sci Hortic 49: 1-8. DOI: 10.1016/0304-4238 (92)90137-2.

Peet MM, Welles G. 2018. Greenhouse tomato production. In: Heuvelink E (ed.) Tomatoes, $2^{\text {nd }}$ ed. CABI, Boston MA.

Pospisil F, Burasova M, Hlava B, Hrachova B, Michl J, Trans The Tuc, Tran Quang Diu, Ngo Xuan Manh, Nguyen Thanh Quynh, Nguyen Van Hoan. 1981. The winged bean - Psophocarpus tetragonolobus (L.) DC. - in Vietnam. Unpublished paper presented in the 2nd International Symposium on Developing the Potentials of the Winged Bean, Colombo, Sri Lanka, January 1981. Abstracted in The Winged Bean Flyer (Agricultural Information Bank for Asia), Laguna, Philippines) 3 (2): 27

Poulter NH. 1982. Some characteristics of the roots of the winged bean (Psophocarpus tetragonolobus (L.) DC.). J Sci Food Agric 33: 107104. DOI: $10.1002 /$ jsfa.2740330202.

Powell JM. 1974. Traditional legumes of the New Guinea highlands. Sci New Guinea 2 (1): 48-62.

Powell JM. 1976. Ethnobotany. In: Paijmans K (ed) New Guinea Vegetation. Australian National University Press, Canberra.

Powell JM, Kulunga A, Moge R, Pono C, Zimike F, Golson J. 1975. Agricultural Traditions of the Mt Hagen Area. Department of Geography Occasional Paper 12. University of Papua New Guinea, Port Moresby.

Prain D. 1903. Psophocarpus Neck. In: Bengal Plants. Botanical Survey of India, Calcutta.

Prescott-Allen R, Prescott-Allen C. 1990. How many plants feed the world? Conserv Biol 4: 365-374. DOI: 10.1111/j.15231739.1990.tb00310.x

PROTA4U 2020. Psophocarpus tetragonolobus (L.) DC. https://www.prota4u.org/database/protav8.asp?g=pe\&p=Psophocarpu s+tetragonolobus+ (L.)+DC.

Price TV. 1980. Diseases of the winged bean. In: The Winged Bean. Papers presented in the 1st International Symposium on Developing the Potentials of the Winged Bean, Manilla, 1978. PCARR, Los Baños, Philippines.

Rachie KO, Luse RA. 1980. Support systems for climbing food crops. In: The Winged Bean. Papers presented in the 1st International Symposium on Developing the Potentials of the Winged Bean, Manilla, 1978. PCARR, Los Baños, Philippines.

Rao PU, Belavady B. 1979. Chemical composition and biological evaluation of goa beans (Psophocarpus tetragonolobus) and their $\begin{array}{lllll}\text { tubers. } & \mathrm{J} & \mathrm{Pl} \text { Foods } 3 & \text { (3): 169-174. DOI: }\end{array}$ 10.1080/0142968X.1979.11904225.

Ronner E, Descheemaeker K, Almekinders CJM, Ebanyat P, Giller KE. 2018. Farmers' use and adaptation of improved climbing bean production practices in the highlands of Uganda. Agric Ecosyst Environ 261: 186-200. DOI: 10.1016/j.agee.2017.09.004

Roxburgh W. 1814. Dolichos tetragonolobus. In: Hortus Bengalensis. Royal Botanic Garden, Serampore. https://www.biodiversitylibrary.org/item/173186\#page/77/mode/1up

Rüegg J. 1981. Effects of temperature and water stress on the growth and yield of winged bean (Psophocarpus tetragonolobus (L.) DC.) J Hortic Sci 56 (4): 331-338. DOI: 10.1080/00221589.1981.11515009.

Rumphius GE. 1747. Lobus quadrangularis. Herbarii Amboinensis 5: 374, t.133.

Safford WE. 1905. Botor tetragonoloba. In: The Useful Plants of the Island of Guam. Contributions from the United States National Herbarium V. 9. Govt. Print. Off., Washington.

Sastrapradja S, Aminah-Lubis SH 1975. Psophocarpus tetragonolobus as a minor garden vegetable in Java. In: Williams JT, et al. (eds.) Southeast Asian Plant Genetic Resources. Proc Symp South East Asian Plant Genetic Resources, Lembaga Biologi Nasional-LIPI, Bogor.

Sastrapradja S, Aminah-Lubis SH, Lubis I, Sastrapradja D. 1978. A survey of variation in Psophocarpus tetragonolobus (L.) DC. with reference to the Javanese samples. Annales Bogorienses 6: 221-230.

Schiavinato MA, Válio IFM. 1996a. Influence of staking on development of winged bean plants. Rev Bras Fisiol Veg (Brazil) 8 (2): 99-103.

Schiavinato MA, Válio IFM. 1996b. Influence of photoperiod and temperature on the development of winged bean plants. Rev Bras Fisiol Veg (Brazil) 8 (2): 105-110.

Schumann K. 1899. Psophocarpus tetragonolobus. Die Flora von Kaiser Wilhelms Land.

Senanayake YDA, Sumanasinghe VAD. 1976. Leaf protein content of Psophocarpus tetragonolobus (L.) DC). J Nat Agric Soc Ceylon 13: 119-121. 
Shet MS, Murugiswamy B, Madaiah M. 1985. A lectin from winged bean, Psophocarpus tetragonolobus, tubers. Ind J Biochem Biophys 22 (5): 313-315.

Shet MS, Madaiah M. 1987. Purification of a lectin from winged bean (Psophocarpus tetragonolobus (L.) DC.) tubers by affinity chromatography. J Sci Food Agric 41 (3): 287-298. DOI: 10.1002/jsfa.2740410311.

Shet MS, Madaiah M, Ahamed RN. 1989. Effect of raw winged bean [Psophocarpus tetragonolobus (L.) DC] tuber lectin on gastrointestinal tract of growing rats. Indian J Exp Biol. 27 (1): 58-61.

Shivashankar G, Reddy SBG. 1984. Induced early and dwarf mutants in winged bean (Psophocarpus tetragonolobus (L.) DC.). The Winged Bean Flyer (Agricultural Information Bank for Asia), Laguna, Philippines) 5 (1): 31-33.

Sri Kantha S. 1986. Nutritional studies on the utilization of winged bean (Psophocarpus tetragonolobus (L.) DC.) seeds and leaves. [Dissertation]. University of Illinois, Urbana-Champaign, IL.

Sri Kantha S, Hettiaracchy NS, Herath HMW, Wickramanayake TW.1978. Studies on the nutritional characteristics of winged bean, Psophocarpus tetragonolobus, tubers and leaves. Proc 34th Ann Session Sri Lanka Assoc Adv Sci 34 (1): 70.

Sri Kantha SS, Erdman JW. 1984. The winged bean as an oil and protein source: A review. J Am Oil Chem Soc 61 (3): 515-525. DOI:10.1007/BF02677021

Stephenson RA. 1980. Field studies on winged bean growth and yield. In: The Winged Bean. Papers presented in the 1st International Symposium on Developing the Potentials of the Winged Bean, Manilla, 1978. PCARR, Los Baños, Philippines.

Stephenson RA, Kesavan V, Claydon A, Bala AA , Kaiulo JV. 1979 Studies on tuber production in winged bean (Psophocarpus tetragonolobus (L.) DC.). In: Belen EH, Villaneuva M (eds) Proceedings of the Fifth International Symposium on Tropical Root and Tuber Crops International Society of Tropical Root Crops, PCARR, Los Baños, Philippines 17-21 September 1979.

Stephenson RA, Drake DW, Kesavan V. 1981. The performance of winged bean (Psophocarpus tetragonolobus (L.) DC.) lines in several environments throughout Papua New Guinea. II. tuber yield responses. The 2nd International Symposium on Developing the Potentials of the Winged Bean. Colombo, Sri Lanka, January 1981 Abstracted in The Winged Bean Flyer (Agricultural Information Bank for Asia), Laguna, Philippines) 3 (2): 22.

Strathern A. 1976. Some notes on the cultivation of winged bean in two highland areas of Papua New Guinea. Sci New Guinea 4 (3): 145 152 .

Tanzi AS, Eagleton GE, Ho WK, Wong QN, Mayes S, Massawe F. 2019a Winged bean (Psophocarpus tetragonolobus (L.) DC.) for food and nutritional security: synthesis of past research and future direction. Planta 250 (3): 911-931. DOI: 10.1007/s00425-019-031412.

Tanzi AS, Ho WK, Massawe F, Mayes S. 2019b. Development and interaction between plant architecture and yield-related traits in winged bean (Psophocarpus tetragonolobus (L.) DC.). Euphytica 215:36. DOI: 10.1007/s10681-019-2359-8.

Taraken IT, Ratsch R. 2009. Sweet potato cultivation on composted mounds in the highlands of Papua New Guinea. ACIAR Technical Reports Series 71: 24-32.

Thiruketheeswaran A, Senanayake YDA. 1981. Mixed cropping of winged bean with snap beans. The 2nd International Symposium on Developing the Potentials of the Winged Bean. Colombo, Sri Lanka, January 1981. Abstracted in The Winged Bean Flyer (Agricultural Information Bank for Asia), Laguna, Philippines) 3 (2): 22-23.

Thompson AE, Haryono SK. 1980. Winged bean: unexploited tropical food crop. HortScience 15 (3): 233-238.

Thompstone E, Sawyer AM. 1914. Psophocarpus tetragonolobus (L.) DC. In: The Peas and Beans of Burma. Agriculture Department of Burma Bulletin 12: 80-84.

Tong TH, Tjong JK, Lubis IP. 1961. Psophocarpus palustris - an ideal ground cover for oil palm and rubber. Proc National Rubber Research Conference, 26 Sept-1 Oct 1960. Rubber Research Institute of Malaysia, Kuala Lumpur, Malaysia.

Verdcourt B, Halliday P. 1978. A revision of Psophocarpus (Leguminosae-Papilionoideae-Phaseoleae). Kew Bulletin 33 (2): 191227. DOI: $10.2307 / 4109575$.
Verdcourt B. 1979. A Manual of New Guinea Legumes. Botany Bulletin No. 11. Office of Forests, Lae, Papua New Guinea.

Wallich N. 1828. Entry 5540C. Psophocarpus tetragonolobus DC. Prome, 1826. In: Numerical List of Dried Specimens of Plants in the Museum of the Honl. East India Company. East India Company Museum, London. https://www.biodiversitylibrary.org/item/15503\#page/204/mode/1up

Warburg O. 1899. Psophocarpus tetragonolobus. In: Das Pflanzenkleid und die Nutzpflanzen von Neu-Guineas. In: Krieger, M. (ed) NeuGuinea. Schall, Berlin.

Watson JB. 1965. From hunting to horticulture in the New Guinea highlands. Ethnology 4 (3): 295-309. DOI: 10.2307/3772989.

Weil RR, Belmont GS. 1991. Dry matter and nitrogen accumulation and partitioning in field grown winged bean. Expl Agric 27 (3): 323-328. DOI: 10.1017/S0014479700019049.

Weil RR, Samaranayake A. 1991. Effects of winged bean on a following maize crop. Expl Agric 27 (3): 329-338. DOI: 10.1017/S0014479700019050.

Wight R, Walker-Arnott GA. 1834. Psophocarpus Neck. In: Prodromus Florae Peninsulae Indiae Orientali. Vol. 1. Parbury, Allen \& Co. London.

Wirz P. 1924. Anthropologische und Ethnologische Ergebnisse der Central Neu-Guinea Expedition 1921-22. In: Beaufort LF, Pulle AA, Rutten L (eds) Nova Guinea, Vol 16. Brill, Leiden.

Wong KC. 1976. The potential for four-angled bean (Psophocarpus tetragonolobus (L.) DC.) in Malaysia to increase food supply. pp 103105 In: Proc Conference on Malaysian Food Self-Sufficiency. University of Malaya, Kuala Lumpur, Malaysia.

Wong KC. 1980. Agronomy of the winged bean in Malaysia. In: The Winged Bean. Papers presented in the 1st International Symposium on Developing the Potentials of the Winged Bean, January 1978, Manila. Philippine Council for Agriculture Resources Research, Los Baños, Laguna, Philippines.

Wong KC. 1983. Effects of Daylength, Temperature, Light Intensity and Applied Growth Substances on the Growth, Flowering and Tuberization of Winged Bean (Psophocarpus tetragonolobus (L.) DC.). [Dissertation] Universiti Pertanian Malaysia, Selangor, Malaysia.

Wong KC, Schwabe WW. 1980. Effects of daylength and day/night temperature on the growth, flowering and tuber formation of winged bean (Psophocarpus tetragonolobus (L.) DC.). In: Proceedings of Legumes in the Tropics, Universiti Pertanian Malaysia, Selangor, Malaysia. pp. 73-85.

Wortmann CS. 2001. Nutrient dynamics in a climbing bean and sorghum crop rotation in the Central Africa Highlands. Nutr Cycl Agroecosystems. 61 (3): 267-272. DOI: 10.1023/A:1013776514526.

Wu D, Mats Thulin. 2010. Psophocarpus Necker ex Candolle. Flora of China 10: 240.

Wulijarni-Soejipto N. 1997. Psophocarpus scandens (Endl.) Verdc. In: Faridah Hanum I, van der Maesen LJG (eds) Plant Resources of South-East Asia No. 11. Auxiliary Plants. Backhuys, Leiden, Netherlands.

Yagi F, Sawada R, Imada T, Toyonaga S, Tadera K, Ishihata K. 1994. Two isolectins from leaves of winged bean, Psophocarpus tetragonolobus (L.) DC. Plant Cell Physiol 35 (7): 1087-1095. DOI: 10.1093/oxfordjournals.pcp.a078698.

Yang SY, Grall A, Chapman MA. 2018. Origin and diversification of winged bean (Psophocarpus tetragonolobus (L.DC.), a multipurpose underutilized legume. Am J Bot 105 (5): 888-897. DOI:10.1002/ajb2.1093.

Yap TN, McDowell RE and Van Soest PJ. 1979. Composition and in-vitro digestibility of the winged bean (Psophocarpus tetragonolobus) and possible utilization of the whole plant in ruminant feed. Malays Appl Biol 8 (2): 119-123.

Yen DE. 1974. The Sweet Potato and Oceania: An Essay in Ethnobotany. Bernice P. Museum Bulletin 2236. Bishop Museum Press, Honolulu.

Yulianah I, Waluyo B, Ashari S, Kuswanto. 2020. Variation in morphological traits of a selection of Indonesian winged bean accessions (Psophocarpus tetragonolobus) and its analysis to assess genetic diversity among accessions. Biodiversitas 21 (7): 2991-3000. DOI: 10.13057/biodiv/d210716. 